University of Texas at El Paso

\title{
DigitalCommons@UTEP
}

Open Access Theses \& Dissertations

2009-01-01

\section{Silica Removal From Brine By Using Ion Exchange}

Carlos R. Acevedo

University of Texas at El Paso, cacevedo@cocef.org

Follow this and additional works at: https://digitalcommons.utep.edu/open_etd

Part of the Environmental Engineering Commons, and the Inorganic Chemistry Commons

\section{Recommended Citation}

Acevedo, Carlos R., "Silica Removal From Brine By Using Ion Exchange" (2009). Open Access Theses \& Dissertations. 2619.

https://digitalcommons.utep.edu/open_etd/2619

This is brought to you for free and open access by DigitalCommons@UTEP. It has been accepted for inclusion in Open Access Theses \& Dissertations

by an authorized administrator of DigitalCommons@UTEP. For more information, please contact lweber@utep.edu. 


\section{SILICA REMOVAL FROM BRINE BY USING ION EXCHANGE}

CARLOS R. ACEVEDO

Department of Chemistry

APPROVED:

Jorge Gardea-Torresdey, Ph.D., Chair

Anthony J. Tarquin, Ph.D., Co-chair

Geoffrey B. Saupe, Ph.D.

Katja Michael, Ph.D.

Patricia D. Witherspoon, Ph.D.

Dean of the Graduate School 
Copyright (C)

by

Carlos R. Acevedo 


\section{Dedication}

To my wife, Sara Sanchez, for her love, patience and help for the accomplishment of this work

To my father, Enrique Acevedo, for his support, guidance and his example of endurance and perseverance

To my mother, Maria del Refugio Rodríguez who always helped me with all of my decisions.

To my children, Carlos, Mayra, Pamela and Andrea, who are the sources of my inspiration. 


\title{
SILICA REMOVAL FROM BRINE BY USING ION EXCHANGE
}

\author{
by \\ Carlos R. Acevedo, Chemical Engineer
}

\section{THESIS}

Presented to the Faculty of the Graduate School of The University of Texas at El Paso

in Partial Fulfillment

of the Requirements

for the Degree of

MASTER OF SCIENCE

Department of Chemistry

THE UNIVERSITY OF TEXAS AT EL PASO

December 2009 


\section{Acknowledgements}

I would like to express my appreciation to Dr. Jorge Gardea-Torresdey who gave me the opportunity and support for the completion of my graduate studies. His excellent teaching and brilliant career have been an example of success and accomplishment that inspired me to accomplish my work.

I also would like to thank Dr. Anthony Tarquin for being such a good teacher and for sharing his enormous experience and talent, with me. He guided my thesis work and always showed his willingness and enthusiasm for assisting me, every time I asked for help.

I am also grateful to Dr. Geoffrey Saupe not only for being a committee member but for his excellent teaching and friendship during my studies.

I appreciate Dr. Peralta for the thorough reading of this document and his meaningful suggestions. His effort indicates the professionalism of his work.

I thank the Jorge Gardea's Group, for their friendship and assistance with the ICP laboratory work.

I also would like to thank the Border Environment Cooperation Commission (BECC) for allowing me to complete my master's degree while working in this excellent institution, and for the financial support that the institution provided to me, special thanks to Javier Torres, Arkelao López, Mario Vazquez, María Elena Giner and Daniel Chacón.

I would like to express my appreciation to my English Teacher, Rosa María Gayou for her great assistance.

Finally I would like to thank my wife Sara for their love patience, and my children Carlos, Mayra, Pamela and Andrea, who are the sources of my inspiration, and for helping me to complete my graduate studies.

I infinitely thank my parents for their love, support and their example of strength that inspired me to succeed. 


\begin{abstract}
Local governments have been forced to look for additional water sources to satisfy the ever increasing demand for fresh water. Very often, the new water sources such as the underground water in continental territories have high salt content. Currently, reverse osmosis technology (RO) is one of the most common processes for water desalination. However, this process is limited by high silica and salt concentrations in water. At high concentrations silica clogs the membranes used in the RO process, reducing their life and increasing operational costs. In this study, quaternary ammonium resins and sulfonic acid resins were used to remove silica and hardness, respectively from brines of both a nanofiltration pilot plant and a synthetic silica solution. Experiments were performed under bath and flow conditions at neutral $\mathrm{pH}$. For batch experiments two anionic quaternary ammonium resins and one cationic sulfonic acid resin were used at 0.02 to $10 \mathrm{~g}$ in $50 \mathrm{~mL}$ of solution to carry out equilibrium tests. The resins were also tested for silica removal from a synthetic solution (without hard cations) at $\mathrm{pH}$ values from 3 to 11 and from brines of a nano-filtration pilot plant (NFPP) at pH ranging from 8 to 10 . For flow experiments, the resins were used at flow rates from 8.7 to $10.5 \mathrm{~cm} / \mathrm{min}$, and $\mathrm{pH}$ values from 8 to 10 . In all cases the amounts of silica and hard cations were determined by inductively coupled plasma optical emission spectroscopy, or by the photometric determination of molybdate-reactive method or using the titrimetic method with EDTA. Results showed that $\mathrm{pH}$ highly influenced silica removal from water solutions using quaternary ammonium resins in the chloride form. For both resins, silica removal efficiencies were higher than $80 \%$ at $\mathrm{pH}>9.0$ and less than $5 \%$ at $\mathrm{pH}<8.0$. Removal efficiency from the synthetic solution was about $62 \%$ and from the brine of the NFPP it was about $14 \%$. The hardness of the brine from the NFPP was found to be about $700 \mathrm{mg} / \mathrm{L}$, which suggests that hard cation complexes in solution limit the efficiency of silica removal using quaternary ammonium resins.
\end{abstract}




\section{Table of Contents}

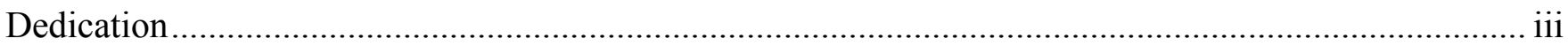

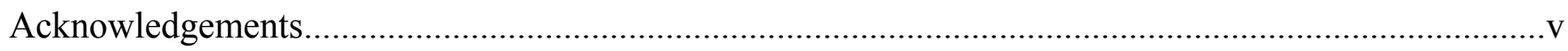

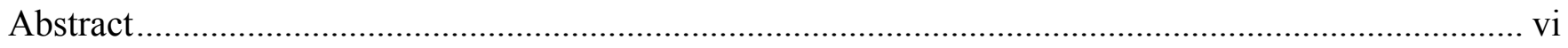

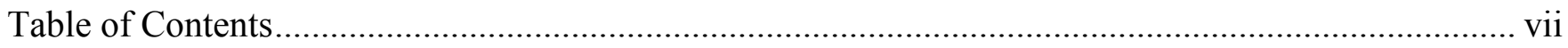

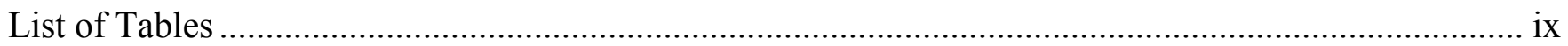

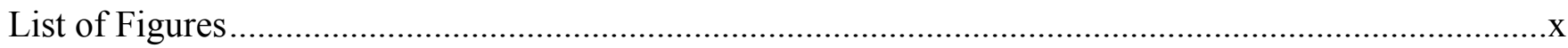

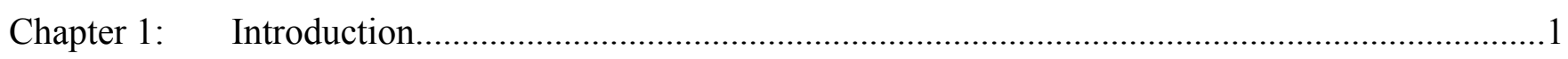

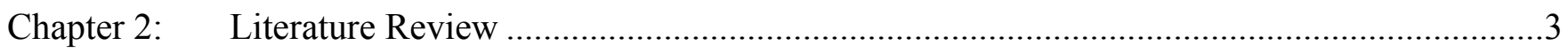

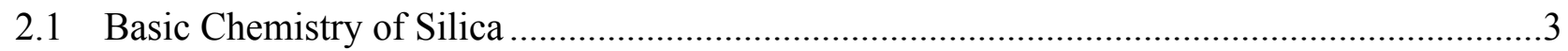

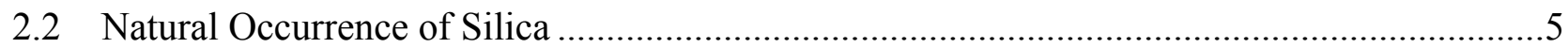

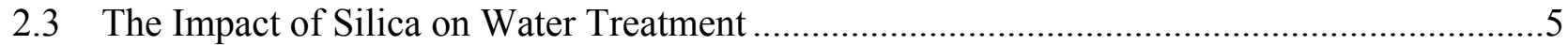

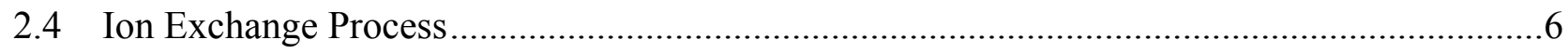

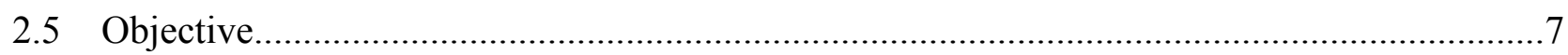

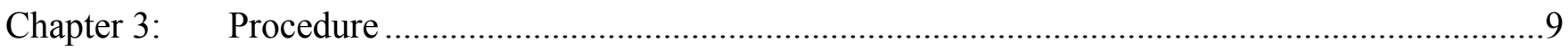

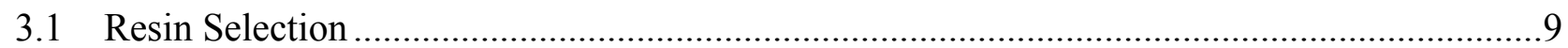

3.2 Silica Removal From Concentrate Generated in a Nano-filtration Pilot Plant ........................9

3.3 Silica Removal From a Synthetic Silica Solution Using Anionic Exchange Resins ..............10

3.4 Removal of Silica Using Quaternary Ammonium Resins Under Flow Conditions .................10

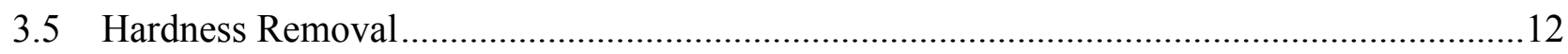

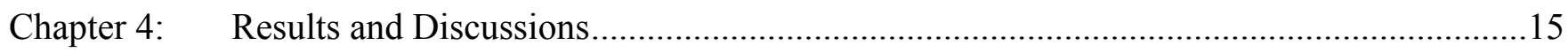

4.1 Silica and Hardness Removal From the Concentrate of a Nano-filtration Pilot Plant:

Batch Experiments............................................................................................................15

4.2 Test for Silica Removal Using an Anionic Exchange Column ..............................................26

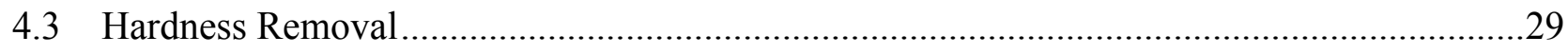

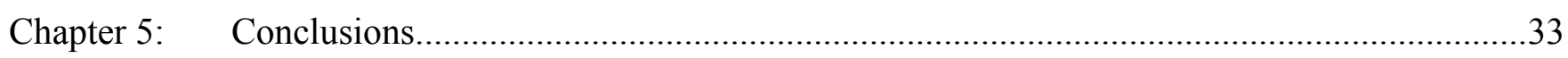

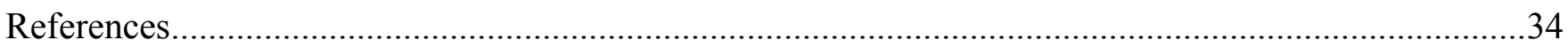

Appendix A

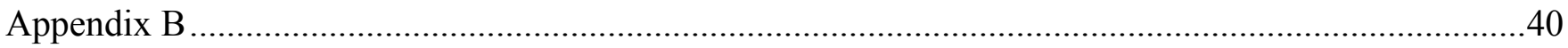




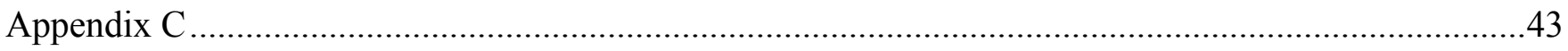

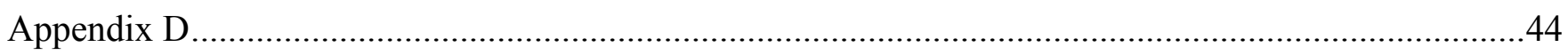

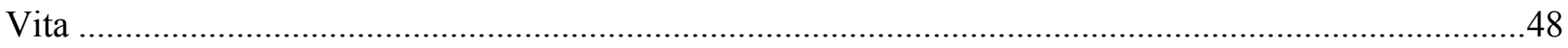




\section{List of Tables}

Table 3.1 - Anionic exchange column characteristics ......................................................... 11

Table 3.2 - Cationic exchange column characteristics .............................................................. 13

Table 4.1 - Removals of $\mathrm{Si}, \mathrm{Ca}$, and $\mathrm{Mg}(\mathrm{mg} / \mathrm{L})$ from a nano-filtration pilot plant concentrate using the resin Dowex 21K XLT

Table 4.2 - Removals of $\mathrm{Si}, \mathrm{Ca}$, and $\mathrm{Mg}(\mathrm{mg} / \mathrm{L})$ from a nano-filtration pilot plant concentrate using the resin Dowex Marathon MSA

Table 4.3 - Removal of silica from a synthetic solution by Dowex 21K XLT (quaternary amine type) in the first cycle. 20

Table 4.4 - Silica removal from a synthetic solution and anionic (quaternary amine type) resin test (second cycle).

Table 4.5 - Silica removal from a synthetic solution and anionic (quaternary amine type) resin test (third step).

Table 4.6 - Silica removal from a synthetic solution and anionic (quaternary amine type) resin test (fourth cycle)

Table 4.7 - Results for silica removal from a synthetic solution and anionic resin Dowex $21 \mathrm{~K}$ XLT at different $\mathrm{pH}$ values

Table 4.8 - Results for silica removal from a synthetic solution using anionic resin Dowex $21 \mathrm{~K}$ XLT under flow conditions

Table 4.9 - Results for silica removal from a concentrate of a NFPP using anionic resin Dowex $21 \mathrm{~K}$ XLT under flow conditions .28

Table 4.10 - Results for hardness removal from a nano-filtration concentrate using cationic resin Bayer

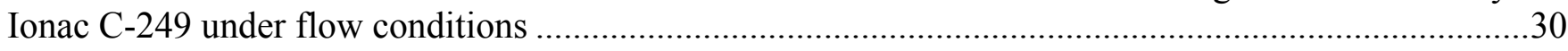

Table 4.11 - - Equilibrium test results for hardness removal 


\section{List of Figures}

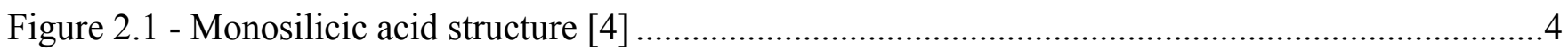

Figure 2.2 - Silica solubility in water at different $\mathrm{pH}$ values......................................................4

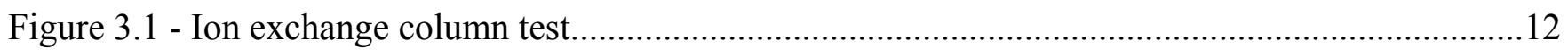

Figure 4.1 - Silica removal by using anionic resin Dowex 21 K XLT ..............................................17

Figure 4.2 - Hardness removal by using anionic resin Dowex 21K XLT ….................................... 17

Figure 4.3 - Silica removal by using anionic resin Dowex Marathon MSA .......................................18

Figure 4.4 - Hardness removal by using cationic resin Dowex G-26............................................. 19

Figure 4.5 - Equilibrium test for silica removal from a synthetic solution and anionic resin .................22

Figure 4.6 - Amount of silica removal from a synthetic solution using anionic resin (batch test)...........23

Figure 4.7 - Percentages Amount of silica removal from a synthetic solution using anionic resin (batch

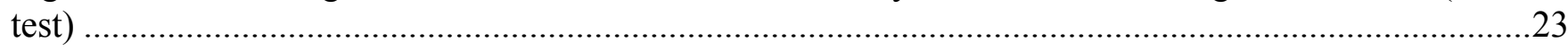

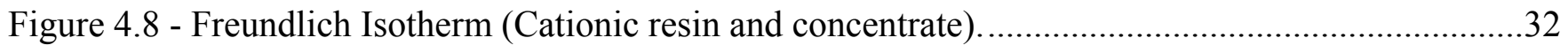




\section{Chapter 1: Introduction}

Water demand worldwide has grown exponentially during the last decades due to the increase in human population. Potable water is scarce and new reliable techniques are needed to make potable undrinkable water. In coastal areas, where fresh water is insufficient, local water utilities have relied on desalination plants to manage the problem. In these regions, reverse osmosis (RO) techniques have been widely used to produce fresh water, generating brine that is returned to the ocean without environmental impact.

Brackish water is also found in several basins in continental territories. For instance, the Hueco Bolson in the City of El Paso, Texas has $600 \%$ more brackish water than potable water. ${ }^{1}$ This water can also be changed to drinkable water using RO, but in this case, brine disposal is an issue that needs to be solved. The City of El Paso has the world's largest inland desalination plant. This facility produces 27.5 million gallons of fresh water daily (MGD). Brine disposal is being done by deep-well injection because it is the most viable alternative. ${ }^{2}$

Other alternatives for brine management are recycling and reduction. Recycling is mainly limited by salt concentrations and especially by silica concentration. Silica can precipitate and clog RO membranes, causing important economic losses. There are several ways to reduce the silica content in brine. This study focused on silica separation, using ion exchange processes. Both anionic and cationic resins were tested to determine the effectiveness of the process. The anionic resin was tested to reduce the silica content and the cationic resin to reduce hardness. (e.g. $\mathrm{Mg}^{2+}, \mathrm{Ca}^{2+}$ )

\footnotetext{
${ }^{1}$ El Paso Water Utilities - Public Service Board Desalination Plant.mht

${ }^{2}$ CDM Inc, Basis of Design Document, Brine Disposal, prepared for El Paso Water Utilities, April, 2002.
} 
DISCLAIMER

Reference to any specific commercial product, process or service by trade name, trademark, manufacturer, or otherwise does not necessarily constitute or imply its endorsement or recommendation. 


\section{Chapter 2: Literature Review}

Water treatment is a complex process that sometimes is controlled by minor components. Silica $\left(\mathrm{SiO}_{2}\right)$ is one of those components that may control the treatment needed for a specific type of water. Silica can create problems with the feed water in cooling towers, boilers, and turbines because of its capability to vaporize and deposit into the turbines' blades, thus damaging them [1]. In the RO process, silica can clog the membranes, reducing their useful life and causing high operational costs $[2,3,4,5]$.

\subsection{BASIC CHEMISTRY OF SILICA}

Silica, in water supplies, is usually found in three different forms: reactive, colloidal and suspended particles [4]. Silica dissolves in water forming the very weak acids $\mathrm{H}_{4} \mathrm{SiO}_{4}$ or $\mathrm{H}_{2} \mathrm{SiO}_{3}$, both of them present as non ionized species [1]. The reaction for silica solubilization is shown in Equation 2.1

$$
\mathrm{SiO}_{2}+2 \mathrm{H}_{2} \mathrm{O} \rightarrow \mathrm{H}_{4} \mathrm{SiO}_{4}
$$

Since silica dissolves in water at neutral $\mathrm{pH}$, it basically appears in the form of non-ionized ortho or meta-silicic acid; this silica is known as reactive silica [1]. The equilibrium equation for monosilicic acid ionization is shown in Equation 2.2

$$
\mathrm{pKa}=\frac{\left[\mathrm{H}_{3} \mathrm{SiO}_{4}\right]\left[\mathrm{H}^{+}\right]}{\left[\mathrm{H}_{4} \mathrm{SiO}_{4}\right]}=9.9
$$

In the hydrated state, monosilicic acid shows a structure formed by two water molecules, which are part of the original structure and four additional water molecules, to contain a total of six water molecules [4].

The structure of the monosilicic acid is shown in Figure 2.1 


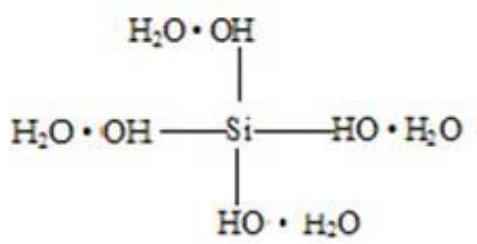

Figure 2.1 - Monosilicic acid structure [4]

If the silica concentration increases, it experiences polymerization. This phenomenon transforms soluble silica to an insoluble gel known as colloidal silica $[4,6]$. Colloidal silica is generally assumed to be multiple polymerized units of silicon dioxide, or a complex of silicon that has reacted with organic or inorganic compounds, usually calcium and aluminum oxides [4].

There are several factors that affect silica solubility in water; the most important are temperature, $\mathrm{pH}$, pressure and the nature of the solid phase $[1,6]$. Silica solubility in nature is also affected by the presence of other ions in water. Iron, manganese, aluminum and even calcium and magnesium affect the equilibrium for silica $[1,6]$. The formation of organic acids, as humic acid, increases the solubility of silica and once the $\mathrm{pH}$ decreases, it forms colloids that are present in many waters around the world [1, $4,6]$.

Figure 2.2 shows the behavior of silica solubility in water at different $\mathrm{pH}$ values. It is observed that solubility increases at $\mathrm{pH}$ lower than 2 and higher than $8.5[1,4]$.

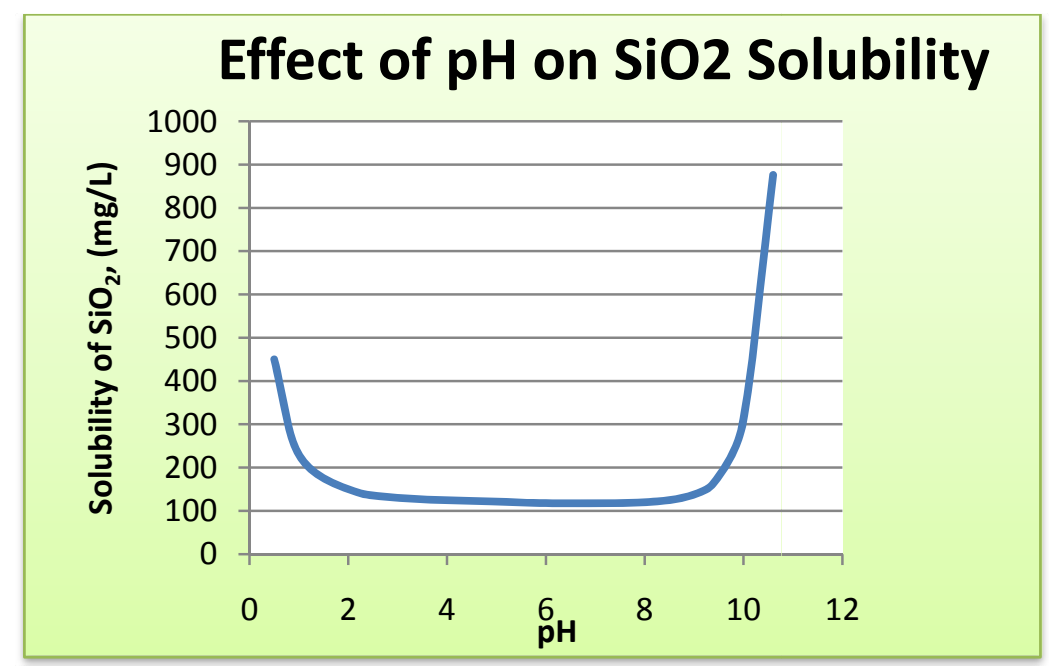

Figure 2.2 - Silica solubility in water at different $\mathrm{pH}$ values 
The most common method to determine the concentration of silica in water is the formation of silicomolybdate complexes. This method applies only to soluble silica (reactive silica) at concentrations below $120 \mathrm{mg} / \mathrm{L}$, at room temperature. Determinations for polymeric silica can be achieved by dissolving the polymer with hydrofluoric acid or by using the gravimetric method (D1428) of the American Society for Testing and Materials (ASTM). [1, 2]

\subsection{NATURAL OCCURRENCE OF Silica}

Almost three quarters of the Earth's lithosphere is silica $\left(\mathrm{SiO}_{2}\right)$. The source of the silica present in water is the siliceous materials, but in general, its concentration is very low due to the low solubility of silicate minerals $[1,3]$. The highest values for silica concentration in nature are found in well water supplies. Most silica is a result of dissolving rocks. On the other hand, surface water tends to contain a higher concentration of colloidal forms of silica $[1,3]$.

The chemistry of silica in surface water supplies becomes more complex since biological activity is involved in the process. Diatoms, a species of algae, assimilate reactive silica dissolved in water to create their protective shell, which is formed by silicon dioxide crystals. Silica, as the active form, is released into the environment once diatoms decompose. The ecological balance between dissolved silica and silicon dioxide structures is complex. Interaction with biological matter will also create the colloidal silica that is present in most surface waters $[1,3]$.

\subsection{ThE IMPACT OF SiLICA ON WATER TREATMENT}

As silica can create several problems in industrial operations such as cooling towers, boilers, turbines, and in processes such as RO or electrodialysis, it is important to remove silica from water in these and other industrial processes $[1,7]$. There are several techniques to remove silica depending on the particular water application, the nature of the silica compounds, and the desired quality of the water. The most important are chemical precipitation, distillation, RO, ultra-filtration and ion exchange [1, 3, 8]. Chemical precipitation is based on the formation of ferric and magnesium silicates that can be further precipitated by adding lime. This process also removes calcium, magnesium and organic matter [1]. 
Distillation is used when high purity water and the elimination of pyroxenes are required [1, 3]. This process is applicable to pharmaceutical operations and related industries but the high cost of energy makes this process unviable for other applications [1]. RO is also applicable for silica removal, but once the resin is clogged by silica, it needs to be replaced $[8,9,10]$. This represents a very high operational cost. Ultra-filtration is sometimes used to remove colloidal silica [1, 3]. Ion exchange can be used to remove reactive silica under specific conditions $[10,11]$. Silica is also found at the lower end of selectivity for anion resins, creating a scenario where silica breakthrough is one of the first to occur. As a result, silica can be effectively removed only if the ion-exchange resins are completely and properly regenerated.

The use of ion exchange to reduce or eliminate silica from the waste brine of an RO desalination plant can improve the efficiency of the process. As stated above, silica can clog membranes if its concentration is high enough to form a precipitate. Whether this occurs, membranes must be replaced making the process expensive and unfeasible.

\subsection{Ion Exchange Process}

The ion exchange process consists of a chemical reaction between ions in a liquid phase and ions in a solid phase. Certain ions in the solution are preferentially sorbed by the ion exchanger solid, and because electroneutrality must be maintained, the solid exchanger releases ions back into the solution.

Ion exchange (IE) resins consist of an organic or inorganic network structure with attached functional groups. Most are synthetic resins made by polymerization of organic compounds into a porous three-dimensional structure. The functional ionic groups are introduced by reacting the polymeric matrix with a chemical compound containing the desired group. IE resins are called cationic if they exchange positive ions and anionic if they exchange negative ions. Also, IE resins are often classified by the nature of their functional group as strong acid, weak acid, strong base or weak base. Strong acid resins are made of styrene and divinylbenzene by sulfonation of the copolymer; weak acid resins contains a carboxyl group (-COOH). Strong base has quaternary ammonium groups $\left(-\mathrm{R}_{3} \mathrm{~N}+\mathrm{OH}-\right)$ and weak base amine groups $\left(-\mathrm{NH}_{2}\right.$ or $\left.-\mathrm{RNH}\right)$. These resins have been previously used to remove silica 
from aqueous solutions $[6,11]$. Among the most widely used quaternary ammonium resins are Dowex 21K XLT and Dowex Marathon MSA [6]. Dowex G26 and Bayer Ionac C-249 were used as cationic resin.

Equation 2.3 shows the basic adsorption process between a cationic resin containing sodium and calcium salts

$$
\mathrm{Na}_{2} \cdot \mathrm{R}+\mathrm{Ca}^{2+} \leftrightarrow \mathrm{Ca} \cdot \mathrm{R}+2 \mathrm{Na}^{+}
$$

The reverse (regeneration) process is shown in equation 2.4

$$
2 \mathrm{Na}^{+}+\mathrm{Ca} \cdot \mathrm{R} \leftrightarrow \mathrm{Na}_{2} \cdot \mathrm{R}+\mathrm{Ca}^{2+}
$$

Within the ionic exchange process, the water to be treated is passed through the resin until available exchange sites are filled and the contaminant appears in the effluent (breakthrough); once the resin is exhausted, the bed is backwashed, regenerated and rinsed with water to begin another cycle [12]. Reports indicate that silica can be virtually completely removed from water [1, 4]. However, characteristics of ion exchange process to remove silica from brines in inland desalination plants were not found in the literature.

\subsection{OBJECTIVE}

The main objective of this research was to use an ion exchange process to remove silica from reverse osmosis concentrate so that additional water could be recovered trough second-pass RO.

\subsubsection{Specific objectives}

The specific objectives of this study were:

1. To test the efficiency of anionic quaternary ammonium resins and cationic resins to remove silica from a nano-filtration concentrate, under batch conditions and neutral $\mathrm{pH}$ (equilibrium capacity studies).

2. To test the efficiency of anionic quaternary ammonium resins and cationic resins to remove silica from a synthetic silica solution, under batch conditions and neutral $\mathrm{pH}$ (equilibrium capacity studies). 
3. To evaluate the effect of $\mathrm{pH}$ on the silica removal efficiency, for ion exchange process.

4. To test the performance of the silica removal using ion exchange and column methods.

5. To carry out test for hardness removal and subsequent silica removal from a concentrate of the nano-filtration plant (cationic and anionic treatment trains).

6. Another objective was to test the regeneration of cationic resins, using salt from an evaporation pond utilized to concentrate the brines of a nano-filtration plant. 


\section{Chapter 3: Procedure}

\subsection{RESIN SELECTION}

This research was performed to determine the type of resin suitable for silica and hardness removal. After reviewing the uses and characteristics of different resin manufacturers, Dowex $21 \mathrm{~K}$ XLT and Dowex Marathon MSA, were selected to remove silica, whereas cationic resins Dowex G-26 and Bayer Ionac C-249 were used to remove hardness. Characteristics of these resins are shown in appendix D.

\subsection{Silla Removal From Concentrate Generated in a NaNo-Filtration Pilot Plant}

The first approach for the present work was to directly test the resins with a concentrate solution, similar to the brines from a RO desalination plant, without changing the resin or water conditions.

Equilibrium tests were performed, using three different types of resins, to evaluate silica, calcium and magnesium removal from a concentrate generated in a nano-filtration pilot plant. Characteristics of the concentrate were: Silica content $\left(\mathrm{as}_{\mathrm{SiO}}\right) 110 \mathrm{mg} / \mathrm{L}$; calcium $6.17 \mathrm{mg} / \mathrm{L}$; magnesium $4.82 \mathrm{mg} / \mathrm{L}$.

Different amounts of resins (from $0.02 \mathrm{~g}$ to $0.5 \mathrm{~g}$ ) were added to $30 \mathrm{~mL}$ plastic tubes that were filled with the concentrate. Equilibrium distribution tests were performed for a period of 24 hours for the Dowex resins 21KXLT, Marathon MSA and G-26 using a Speci-Mix Thermolyne model M26125 (Barnstead International, Dubuque IA). Liquid phase samples were filtered through $0.45 \mu \mathrm{m}$ Whatman filters. Initial and final concentrations of silica, calcium, and magnesium were determined by using inductively coupled plasma-optical emission spectroscopy (ICP-OES) (Perkin-Elmer, Optima 4300 DV, Shelton, CT). 


\subsection{Silica Removal From a Synthetic Silica Solution USing ANionic Exchange ReSins}

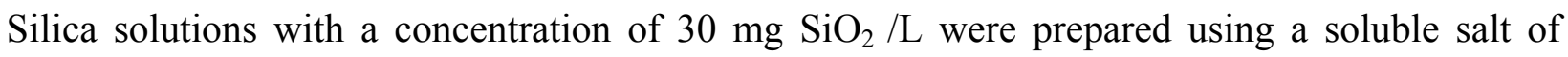
sodium metasilicate $\left(\mathrm{Na}_{2} \mathrm{SiO}_{3} \cdot 9 \mathrm{H}_{2} \mathrm{O}\right)$ and deionized $\mathrm{RO}$ water, to perform batch equilibrium distribution tests using anionic resin Dowex $21 \mathrm{~K}$ XLT. Amounts of resin ranging from 0.34 to $1.05 \mathrm{~g}$ were added to $50 \mathrm{~mL}$ plastic tubes that were filled with the silica solution and agitated for 24 hours to allow equilibrium. Tests were carried out without controlling the $\mathrm{pH}$ of the equilibrium solutions.

Liquid phase samples were pulled at the completion of the tests and filtered through $0.45 \mu \mathrm{m}$ Whatman filters. The concentration of $\mathrm{SiO}_{2}$ was determined using the photometric determination of molybdate-reactive method $^{3}$ [6] and a spectrophotometer HACH model DR4000U (Loveland, CO). Tests were repeated four times with the same previously used resin, with new aliquots of $\mathrm{SiO}_{2}$ solution to evaluate the behavior of the process in the sequential batches.

\subsubsection{Influence of $\mathbf{p H}$ upon equilibrium}

Tests were performed to determine changes in the $\mathrm{pH}$ of the solution associated with changes in the amount of resins. Additional equilibrium tests were carried out using the same technique but adjusting the $\mathrm{pH}$ from 11.1 to 3.27 with sodium hydroxide $(\mathrm{NaOH})$ and sulfuric acid $\left(\mathrm{H}_{2} \mathrm{~S}_{4}\right)$. For this study, an initial concentration of $31 \mathrm{mg} \mathrm{SiO}_{2} / \mathrm{L}$ was used, resin was weighted directly in the tubes and $50 \mathrm{~mL}$ of sample were added. The $\mathrm{pH}$ was adjusted with $\mathrm{NaOH} / \mathrm{H}_{2} \mathrm{SO}_{4}$ and mixed for $24 \mathrm{~h}$. Two series of experiments were run using two samples of resins and one sample of water for each pH value.

\subsection{Removal OF Silica USING QUATERNARY AMmoniUm RESINS UNDER FLOW CONDITIONS}

As part of this research, silica removal using an ion exchange column was also performed. For this experiment, a solution using deionized $\mathrm{RO}$ water and sodium metasilicate with a silica concentration of $40 \mathrm{mg} / \mathrm{L}$ was prepared. The $\mathrm{pH}$ was adjusted to $8.5 \mathrm{using}$ a solution $0.1 \mathrm{M}$ of sodium hydroxide. This

\footnotetext{
${ }^{3}$ Method ASTM 4500- $\mathrm{SiO}_{2} \mathrm{C}$.
} 
$\mathrm{pH}$ was initially selected to test the silica removal efficiency at a moderately high $\mathrm{pH}$ without adding large amounts of basic that make this process expensive and prohibiting for industrial use.

A glass tube was cleaned with diluted acid solution and rinsed with deionized water. Subsequently, it was filled with quaternary ammonium anionic resin Dowex $21 \mathrm{~K}$ XLT to make an anionic exchange column. The minimum recommended height of the column, according to the Dowex resin data sheet was $80 \mathrm{~cm}$. The resin was washed with deionized RO water before beginning the test to reduce the effect of the free acidity in the resin. Characteristics of the column are summarized in Table 3.1. The flow rate was adjusted using a peristaltic pump, as shown in figure 3.1. Flow rates from 1.8 to 5 $\mathrm{mL} / \mathrm{min}$ were tested; samples were collected approximately every 10 minutes, and the silica concentration was measured using a spectrophotometer Hach-DR4000U.

Table 3.1 - Anionic exchange column characteristics

\begin{tabular}{|l|c|}
\hline \multicolumn{2}{|c|}{ Anionic Exchange Column } \\
\hline $\begin{array}{l}\text { Anionic exchange resin } \\
\text { volume }\end{array}$ & $29.4 \mathrm{~mL}$ \\
\hline Column diameter & $0.604 \mathrm{~cm}$. \\
\hline Bed height & $102.5 \mathrm{~cm}$. \\
\hline $\begin{array}{l}\text { Detention time with void } \\
\text { bed }\end{array}$ & $11.18 \mathrm{~min}$ \\
\hline Average flow & $2.5 \mathrm{~mL} / \mathrm{min}$ \\
\hline Type of flow & Ascendant \\
\hline
\end{tabular}




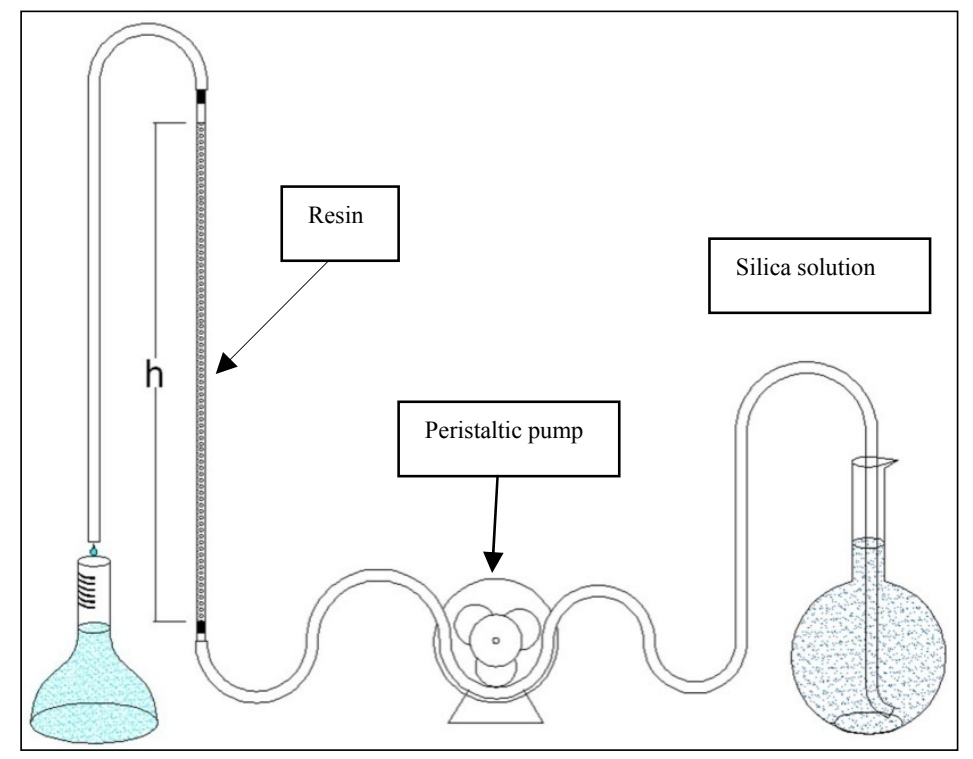

Figure 3.1 - Ion exchange column test

Other experiments were performed using the concentrate of the nano-filtration process to test the efficiency of silica removal from these kinds of solutions. The methodology used to perform the tests was the same as described above. In these experiments, $15 \mathrm{~g}$ of Dowex $21 \mathrm{KXLT}$ anionic exchange resin with average ascendant flow of $3.5 \mathrm{~mL} / \mathrm{min}$ was used. The initial $\mathrm{SiO}_{2}$ concentration was $153.6 \mathrm{mg} / \mathrm{L}$ and total hardness was $730 \mathrm{mg} / \mathrm{L}$. The $\mathrm{pH}$ was adjusted to 8.08 using sodium hydroxide, because at higher $\mathrm{pH}$ precipitation of calcium and magnesium occurred.

\subsection{HARDNESS REMOVAL}

\subsubsection{Ion exchange columns}

Hardness removal using ion exchange has been successfully used for many years. In this study, tests for hardness removal were carried out to prove the effectiveness for this method, to remove cations, and subsequently, remove silica.

For this experiment, a solution from the nano-filtration pilot plant (NFPP) with an initial hardness of $690 \mathrm{mg} / \mathrm{L}$ (measured using the EDTA method) was used. A glass tube was filled with 
cationic resin Bayer Ionac C-249 to make an exchange column. The resin was washed with $\mathrm{RO} /$ deionized water before the beginning of the test. The characteristics of the column are summarized in Table 3.2. A flow rate of $20 \mathrm{~mL} / \mathrm{min}$ was tested and samples were collected approximately every 50 $\mathrm{mL}$.

Table 3.2 - Cationic exchange column characteristics

\begin{tabular}{|l|c|}
\hline \multicolumn{2}{|c|}{ Anionic Exchange Column } \\
\hline Cationic resin volume & $30 \mathrm{~mL}$ \\
\hline Column diameter & $0.604 \mathrm{~cm}$ \\
\hline Bed height & $104 \mathrm{~cm}$ \\
\hline $\begin{array}{l}\text { Detention time with void } \\
\text { bed }\end{array}$ & $1.49 \mathrm{~min}$ \\
\hline Average flow & $20 \mathrm{~mL} / \mathrm{min}$ \\
\hline Type of flow & Ascendant \\
\hline
\end{tabular}

\subsubsection{Equilibrium tests for hardness removal}

For these tests, samples from the NFPP were set in $50 \mathrm{~mL}$ plastic tubes filled with resin Bayer Ionac C-249. Equilibrium distribution tests were performed using a mixing device for a period of 24 hours. Liquid phase samples were filtered through $0.45 \mu \mathrm{m}$ Whatman filters and hardness was measured by titrimetic method with EDTA.

\subsubsection{Tests for the use of recovered salt as regenerant for cationic resins}

Besides the tests for silica and hardness removal, another test to find out the possibility for the use of salt recovered from evaporation ponds, used in another research for brine disposal alternatives, was performed.

For this test, a saturated solution was prepared using the recovered salt sample, and distilled water. This solution was passed through a column containing previously used cationic resin Bayer Ionac C-249. 
Hardness of the salt solution after passing the column was tested using the titrimetic method with EDTA. Regeneration solution flow was continued until reaching a concentration lower than $40 \mathrm{mg} / \mathrm{L}$ in the effluent. 


\section{Chapter 4: Results and Discussions}

\subsection{Silica ANd Hardness Removal From the Concentrate of a Nano-filtration Pilot PLANT: BATCH EXPERIMENTS}

\subsubsection{Silica removal from concentrate generated in a nano-filtration pilot plant}

To determine silica, calcium and magnesium concentrations in the nano-filtration concentrate, tests with diluted 1:10 samples in distilled water were performed. The data showed that the nanofiltration concentrate had the following concentrations: $\left[\mathrm{SiO}_{2}\right]=125 \mathrm{mg} / \mathrm{L},[\mathrm{Ca}]=6.2 \mathrm{mg} / \mathrm{L} .[\mathrm{Mg}]=4.8$ $\mathrm{mg} / \mathrm{L}$.

Results for silica removal from the concentrate generated in the NFPP, after a mixing period of $24 \mathrm{~h}$, using the resin Dowex 21KXLT are shown in Table 4.1.

Table 4.1 - Removals of Si, Ca, and Mg (mg/L) from a nano-filtration pilot plant concentrate using the resin Dowex 21K XLT

\begin{tabular}{|c|c|c|c|c|}
\hline $\begin{array}{c}\text { Sample } \\
\text { Number }\end{array}$ & $\begin{array}{c}\text { Amount of } \\
\text { resin }(\mathrm{g})\end{array}$ & $\begin{array}{c}\mathrm{Si}(\mathrm{mg} / \mathrm{L}) \\
212^{*}\end{array}$ & $\begin{array}{c}\mathrm{Ca}(\mathrm{mg} / \mathrm{L}) \\
228^{*}\end{array}$ & $\begin{array}{c}\mathrm{Mg}(\mathrm{mg} / \mathrm{L}) \\
279^{*}\end{array}$ \\
\hline 1 & 0.022 & 100 & N.D. & 4.56 \\
\hline 2 & 0.046 & 102 & 5.96 & 4.61 \\
\hline 3 & 0.066 & 102 & 5.96 & 4.63 \\
\hline 4 & 0.082 & 102 & 6.08 & 4.68 \\
\hline 5 & 0.108 & 104 & 6.18 & 4.72 \\
\hline 6 & 0.500 & 105 & 6.24 & 4.80 \\
\hline 7 & 0.022 & 105 & 6.30 & 4.76 \\
\hline 8 & 0.046 & 105 & 6.23 & 4.74 \\
\hline 9 & 0.062 & 105 & 6.29 & 4.79 \\
\hline 10 & 0.086 & 104 & 6.25 & 4.86 \\
\hline 11 & 0.104 & 104 & 6.24 & 4.81 \\
\hline 12 & 0.500 & 103 & 6.33 & 5.66 \\
\hline
\end{tabular}

*wavelength for the ICP Test

Samples from 7 to 12 were duplicates of sample 1 to 6 , respectively. The data showed that silica concentrations remained very similar. Furthermore, a faintly backward behavior was observed. Slightly more silica was removed with less amounts of resin. As seen in Table 4.1, there was not a clear trend for 
the amount of resins and the silica removed from the liquid phase. The lowest silica concentration corresponded to the smaller amount of resin (0.022), but the highest silica concentration corresponded to several resin samples. Values for calcium and magnesium remained approximately constant. It is very likely that the neutral $\mathrm{pH}$ of the water avoided the dissociation of the metasilicic acid to form the ion $\left[\mathrm{H}_{3} \mathrm{SiO}_{4}\right]^{-}$; thus the un-dissociated form of this compound did not have the capacity for ionic attraction to the binding site of the resin. Additionally, the presence of anions such as sulfate, chloride or phosphate in solution, with higher affinity for the anionic resin, prevented the attraction of the ion $\left[\mathrm{H}_{3} \mathrm{SiO}_{4}\right]^{-}$.

The first dissociation of the metasilicic acid is shown in the equation 4.1:

$$
\mathrm{H}_{4} \mathrm{SiO}_{4} \leftrightarrow\left[\mathrm{H}_{3} \mathrm{SiO}_{4}^{-}\right]+\left[\mathrm{H}^{+}\right]
$$

In this process, the presence of $\mathrm{OH}$ - displaces the equilibrium of the dissociation to the right, while the free acidity in the resin reduces the concentration of $\mathrm{OH}$ - ions. Therefore, the equilibrium of the dissociation is displaced to the left. This could explain the backward behavior of the equilibrium between the amount of resin and the silica removed (Table 4.1). From these results, it can be assumed that the effect of the acidity was more important than the amount of resin. The concentrations of calcium and magnesium remained almost constant because the resin had no attraction for cations.

Removals of silica by the quaternary ammonium resin (resin Dowex Marathon MSA) are shown in Table 4.2.

Table 4.2 - Removals of Si, Ca, and Mg (mg/L) from a nano-filtration pilot plant concentrate using the resin Dowex Marathon MSA

\begin{tabular}{|c|c|c|c|c|}
\hline $\begin{array}{c}\text { Sample } \\
\text { Number }\end{array}$ & $\begin{array}{c}\text { Amount of } \\
\text { resin }(\mathrm{g})\end{array}$ & $\begin{array}{c}\mathrm{Si} \text { as } \mathrm{SiO}_{2} \\
(\mathrm{mg} / \mathrm{L}) \\
212\end{array}$ & $\begin{array}{c}\mathrm{Ca} \\
(\mathrm{mg} / \mathrm{L}) \\
228\end{array}$ & $\begin{array}{c}\mathrm{Mg}(\mathrm{mg} / \mathrm{L}) \\
279\end{array}$ \\
\hline 13 & 0.505 & 102 & 6.11 & 4.86 \\
\hline 14 & 0.025 & 104 & 6.12 & 4.86 \\
\hline 15 & 0.044 & 104 & 6.09 & 4.85 \\
\hline 16 & 0.062 & 104 & 6.12 & 4.87 \\
\hline 17 & 0.083 & 104 & & \\
\hline
\end{tabular}

As seen in this table, the concentration of silica, calcium, and magnesium remained approximately constant. 
Figure 4.1 shows results for the anionic resin Dowex $21 \mathrm{~K}$ XLT. In this figure the " $\mathrm{y}$ " axis represents the remained concentration of silica in the solution and the " $\mathrm{x}$ " axis represents the amount of resin added. As shown in this figure there was no clear relationship between the amount of resin utilized and the silica concentration.

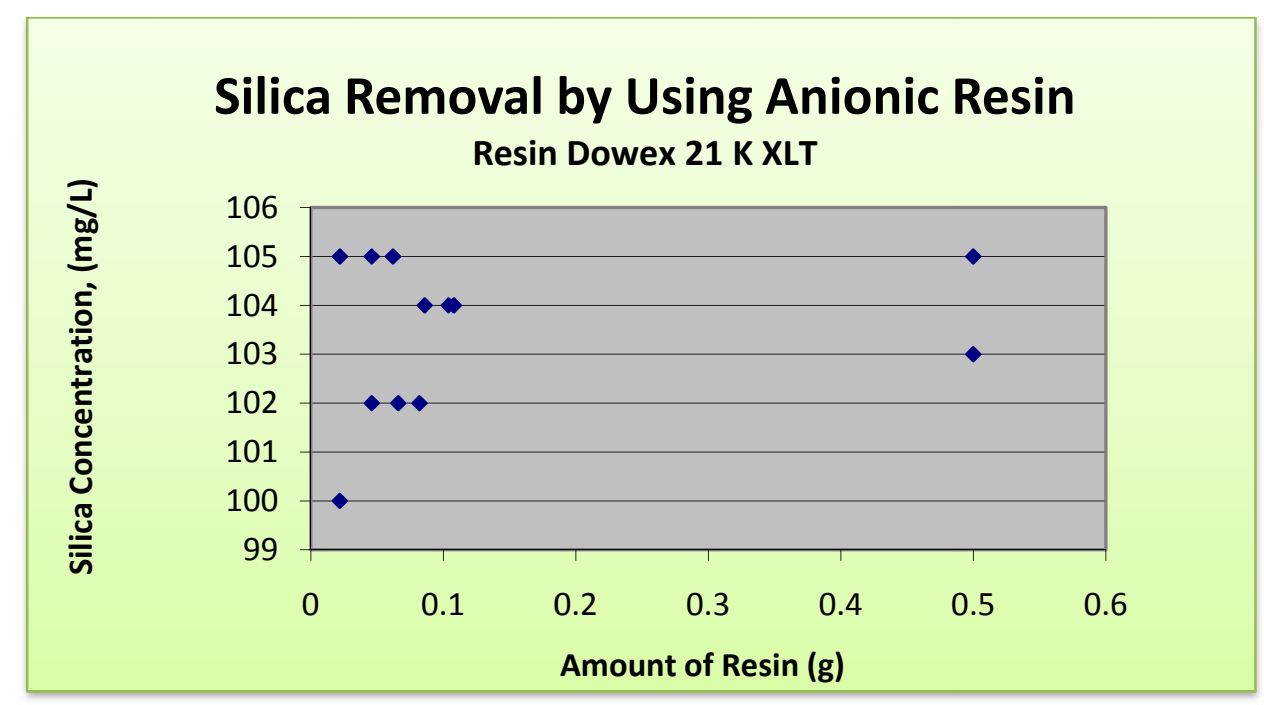

Figure 4.1 - Silica removal by using anionic resin Dowex 21 K XLT

For this test, concentrations of calcium and magnesium remained approximately constant as shown in Figure 4.2. Since the anionic resin has no influence on the cations, no changes were experienced in both calcium and magnesium concentrations.

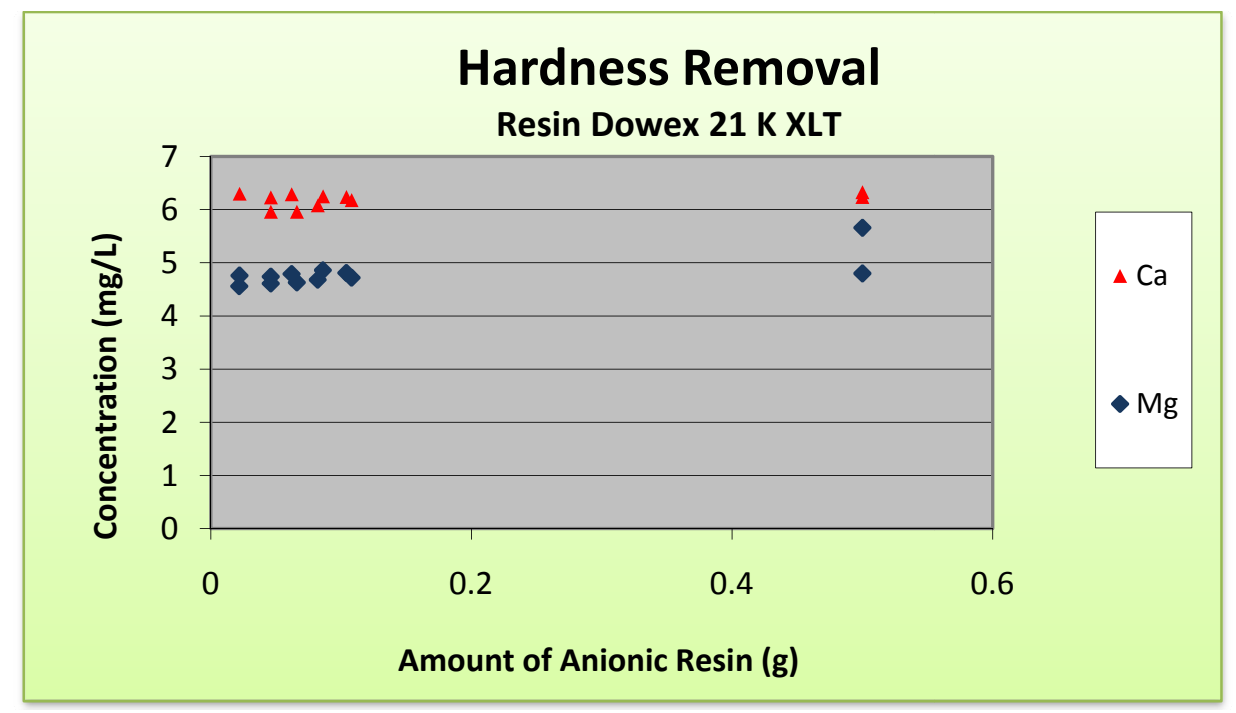

Figure 4.2 - Hardness removal by using anionic resin Dowex 21K XLT 
Results for the use of the resin Dowex Marathon MSA at $<0.1 \mathrm{~g}$ showed values of silica concentration approximately constants $(104 \mathrm{mg} / \mathrm{L})$, while at $0.505 \mathrm{~g}$ the results was about $102 \mathrm{mg} / \mathrm{L}$ (Figure 4.3).

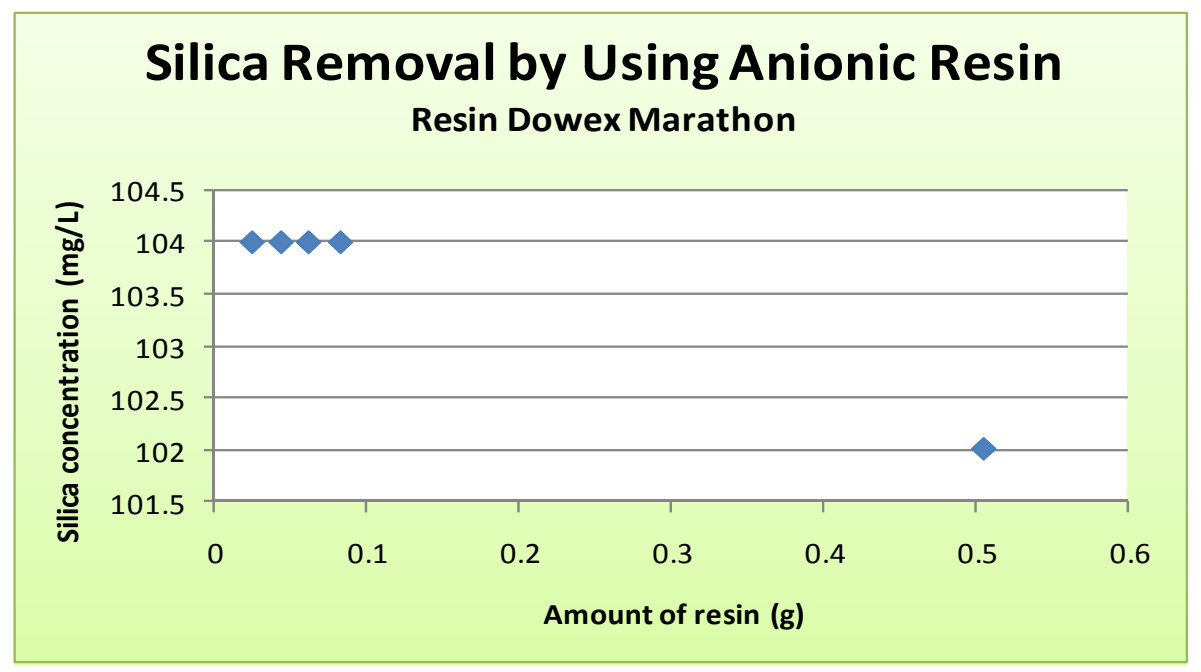

Figure 4.3 - Silica removal by using anionic resin Dowex Marathon MSA

\subsubsection{Hardness removal from concentrate generated in a nano-filtration pilot plant}

The use of the cationic resin G-26 to remove silica from salt solutions is mentioned in the technical information of the Dowex ion exchange resins. This resin was also tested in conjunction with the two anionic resins to evaluate the possibility for silica removal, besides the effectiveness for hardness removal. For this test, results showed significant removal of calcium and magnesium. In this case, higher removal corresponded to higher amounts of resin.

The DOWEX resin G-26 did not show any effect on silica removal; however, as shown in Figure 4.4, calcium and magnesium concentration confirmed the effectiveness of resin for hardness removed. 


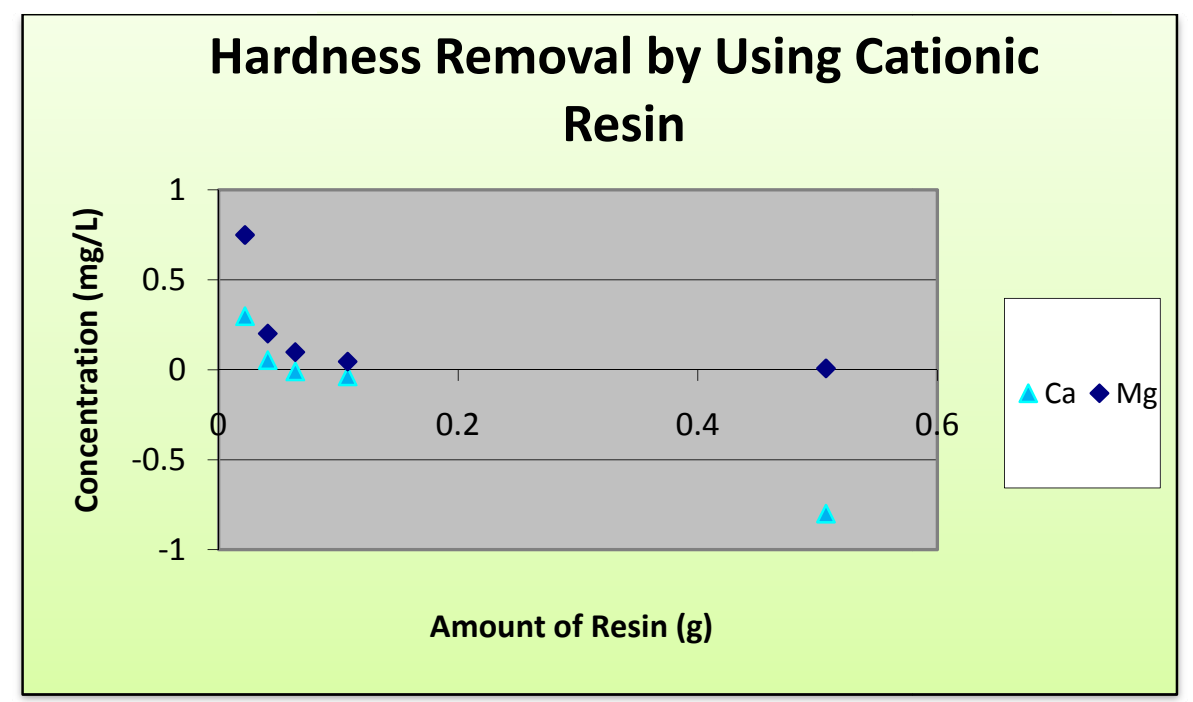

Figure 4.4 - Hardness removal by using cationic resin Dowex G-26

Figure 4.4 shows that Dowex G-26 resin used at $>0.06 \mathrm{~g}$ removed all calcium and most of magnesium.

\subsubsection{Overall results for silica and hardness removal from concentrate generated in a nano- filtration pilot plant}

Results of the tests can be summarized as follows:

- Maximum silica removal corresponds to the sample No. 1, (using the smallest amount of resin) and was only $9 \%$ removal.

- $\quad$ Silica removal efficiency was very low for the three resins used in the tests.

- Backward behavior was observed for silica removal and the amount of resin; more removal was obtained with less resin.

- $\quad$ Calcium and magnesium removal was successfully done by the cationic resin.

- $\quad$ Both anionic resins showed similar results.

In order to evaluate the behavior of the silica removal without the interference of other ions dissolved in the concentrate of the nano-filtration pilot plant, other series of experiments were performed, using pure water and sodium metasilicate to prepare a silica solution. 


\subsubsection{Silica Removal from a synthetic solution of sodium metasilicate}

Due to the fact that the $\mathrm{SiO}_{2}$ removal from the nano-filtration using the anionic resins was very low, new experiments were performed using the synthetic solution described in Section 3.3. This solution was deprived of the hard cations $\mathrm{Ca}$ and $\mathrm{Mg}$. In these experiments, $\mathrm{SiO}_{2}$ concentrations were determined using the molybdate method [6]. Tests were performed in duplicate and repeated four times with the same resin. Results for the first of the four cycles showed a backward behavior in which higher amount of resin corresponded to smaller silica removal (Table 4.3). This result supported the hypothesis that the free acidity of the resin affected the dissociation of the silicic acid, thus the ion exchange performance. Results for the test are summarized in Table 4.3.

Table 4.3 - Removal of silica from a synthetic solution by Dowex 21K XLT (quaternary amine type) in the first cycle

\begin{tabular}{|c|c|c|c|}
\hline $\begin{array}{c}\text { Amount of Resin } \\
(\mathrm{g})\end{array}$ & $\begin{array}{c}\text { Final } \\
\text { Concentration } \\
\left(\mathrm{mg} / \mathrm{L} \text { of } \mathrm{SiO}_{2}\right) \\
\text { First cycle }\end{array}$ & $\begin{array}{c}\text { Removal } \\
\text { efficiency (\%) }\end{array}$ & $\begin{array}{c}\text { Amount of Silica } \\
\text { Removed (mg) }\end{array}$ \\
\hline 0.34 & 6 & 80.0 & 1.19 \\
\hline 0.34 & 6.1 & 79.7 & 1.18 \\
\hline 0.67 & 7.2 & 76.0 & 1.12 \\
\hline 0.67 & 7.3 & 75.7 & 1.11 \\
\hline 5.03 & 17.5 & 41.7 & 0.53 \\
\hline 5.03 & 16.7 & 44.3 & 0.57 \\
\hline 10.05 & 23.3 & 22.3 & 0.23 \\
\hline 10.05 & 24.2 & 19.3 & 0.20 \\
\hline
\end{tabular}

As stated above, tests were repeated four times with the same resin using new aliquots of $\mathrm{SiO}_{2}$ solution. Results for the second cycle of the tests were reported in Table 4.4 
Table 4.4 - Silica removal from a synthetic solution and anionic (quaternary amine type) resin test (second cycle)

\begin{tabular}{|c|c|c|c|}
\hline $\begin{array}{c}\text { Amount of Resin } \\
(\mathrm{g})\end{array}$ & $\begin{array}{c}\text { Final } \\
\text { Concentration } \\
\left(\mathrm{mg} / \mathrm{L}_{\left.\text {of } \mathrm{SiO}_{2}\right)}\right)\end{array}$ & $\begin{array}{c}\text { Removal } \\
\text { Second cycle }\end{array}$ & $\begin{array}{c}\text { Amount of Silica } \\
\text { Removed (mg) }\end{array}$ \\
\hline 0.34 & 7.7 & 74.3 & 1.1 \\
\hline 0.34 & 7.5 & 75 & 1.11 \\
\hline 0.67 & 7 & 76.7 & 1.13 \\
\hline 0.67 & 7.3 & 75.7 & 1.11 \\
\hline 1.68 & 8.4 & 72 & 1.03 \\
\hline 1.68 & 8.4 & 72 & 1.03 \\
\hline 3.35 & 6 & 80 & 1.08 \\
\hline 3.35 & 6 & 80 & 1.08 \\
\hline 5.03 & 8.8 & 70.7 & 0.9 \\
\hline 5.03 & 9.2 & 69.3 & 0.88 \\
\hline
\end{tabular}

For the second cycle, the silica removal efficiency ranged between 70 and $80 \%$, reducing the slope of the backward behavior; equilibrium silica concentration ranged between 7 and 9.2 and the amount of silica removed ranged from 0.88 to 1.11 .

A third and fourth test were repeated in the same manner of the second test. Results showed again a reduction of the backward behavior. Table 4.5 and 4.6 report the values for the final silica concentration, removal efficiency and the amounts of silica removed during the third and fourth cycles, respectively.

Table 4.5 - Silica removal from a synthetic solution and anionic (quaternary amine type) resin test (third step)

\begin{tabular}{|c|c|c|c|}
\hline $\begin{array}{c}\text { Amount of Resin } \\
(\mathrm{g})\end{array}$ & $\begin{array}{c}\text { Final } \\
\text { Concentration } \\
\left(\mathrm{mg} / \mathrm{L} \mathrm{of} \mathrm{SiO}_{2}\right) \\
\text { Third cycle }\end{array}$ & $\begin{array}{c}\text { Removal } \\
\text { efficiency (\%) }\end{array}$ & $\begin{array}{c}\text { Amount of Silica } \\
\text { Removed (mg) }\end{array}$ \\
\hline 1.68 & 7.0 & 76.7 & 1.09 \\
\hline 1.68 & 7.6 & 74.7 & 1.06 \\
\hline 3.35 & 7.1 & 76.3 & 1.03 \\
\hline 3.35 & 7.2 & 76.0 & 1.03 \\
\hline 5.03 & 9.3 & 69.3 & 0.88 \\
\hline 5.03 & 9.2 & 69.0 & 0.88 \\
\hline
\end{tabular}


For the third cycle, silica removal efficiency ranged between 69 and $77 \%$, very similar to the second cycle and still presented a slightly backward behavior.

Table 4.6 - Silica removal from a synthetic solution and anionic (quaternary amine type) resin test (fourth cycle)

\begin{tabular}{|c|c|c|c|}
\hline $\begin{array}{c}\text { Amount of Resin } \\
(\mathrm{g})\end{array}$ & $\begin{array}{c}\text { Final } \\
\text { Concentration } \\
\left(\mathrm{mg} / \mathrm{L}_{\text {of }} \mathrm{SiO}_{2}\right) \\
\text { Fourth step. }\end{array}$ & $\begin{array}{c}\text { Removal } \\
\text { efficiency (\%) }\end{array}$ & $\begin{array}{c}\text { Amount of Silica } \\
\text { Removed (mg) }\end{array}$ \\
\hline 1.68 & 6.4 & 78.7 & 1.06 \\
\hline 1.68 & 6.5 & 78.3 & 1.06 \\
\hline 3.35 & 6.6 & 78.0 & 1.11 \\
\hline 3.35 & 6.7 & 77.7 & 1.11 \\
\hline
\end{tabular}

The range for silica removal efficiencies in the fourth cycle were even smaller; removal efficiencies ranged from $77.7 \%$, using $3.35 \mathrm{~g}$ of anionic resin to $78.7 \%$, using $1.68 \mathrm{~g}$ of anionic resin. The backward behavior was diminished in each of the four tests. This may be explained by the dilution of the acidity present in the resin, which influences the silica dissociation.

Overall results for the four cycles are shown in the Figure 4.10.

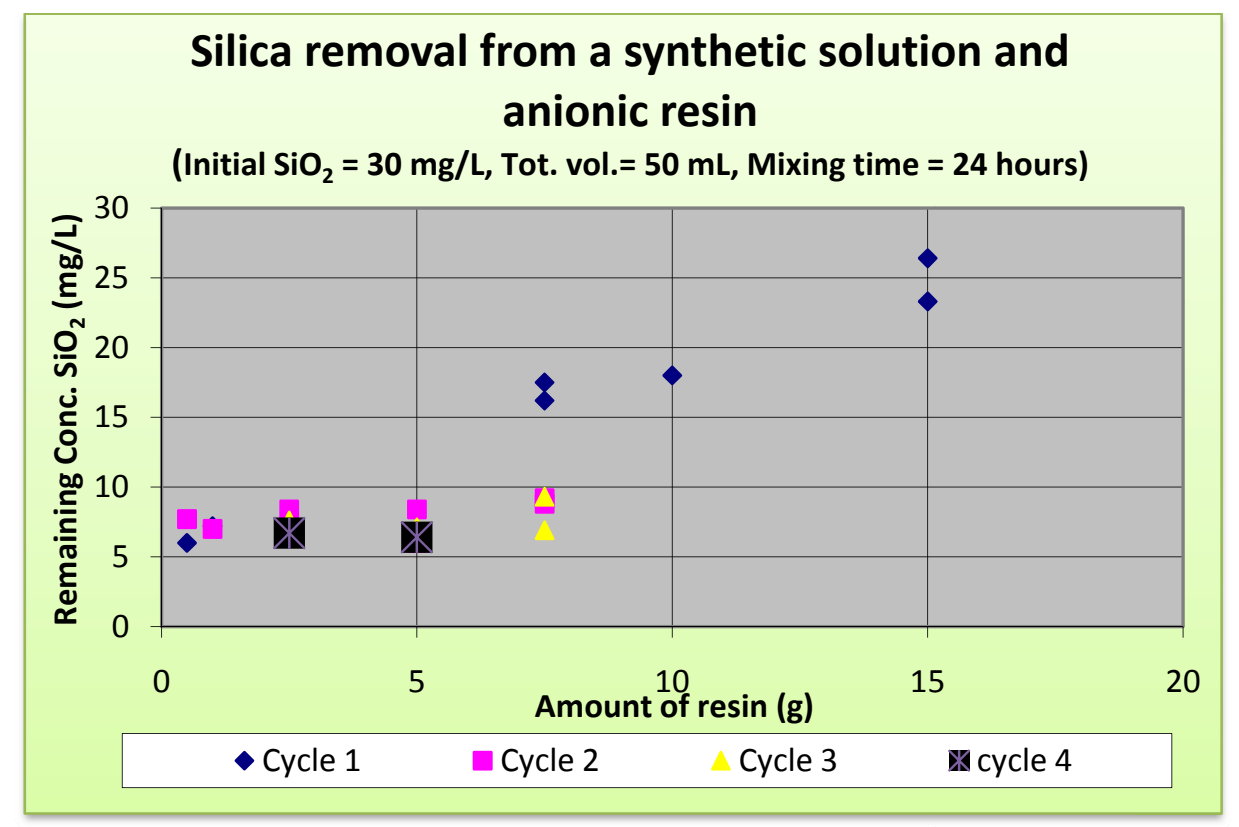

Figure 4.5 - Equilibrium test for silica removal from a synthetic solution and anionic resin

The amount of silica removed during each test was calculated and is shown in Figure 4.11. 


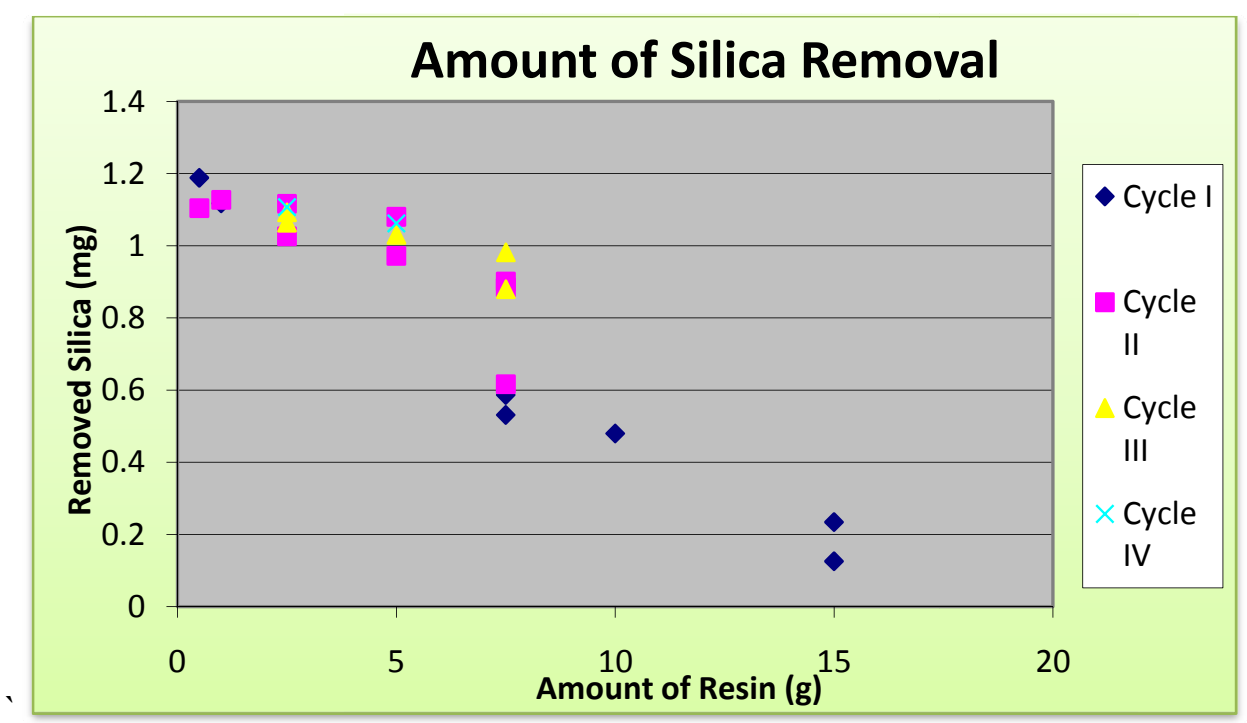

Figure 4.6 - Amount of silica removal from a synthetic solution using anionic resin (batch test)

During the first cycle, a variation of approximately $1 \mathrm{mg}$ (maximum and minimum) was observed; whereas the variation for the third cycle was less than one mg. Figure 4.6 and Figure 4.7 show the amounts of silica removed from solution (raw data and percentages, respectively). As shown in these figures the backward behavior and the range of concentrations were reduced in every cycle. In addition, the percentage data showed that the slope for the third and fourth cycle were positive, indicating that the backward behavior was almost eliminated, probably due to the dilution of the free acidity of the resin.

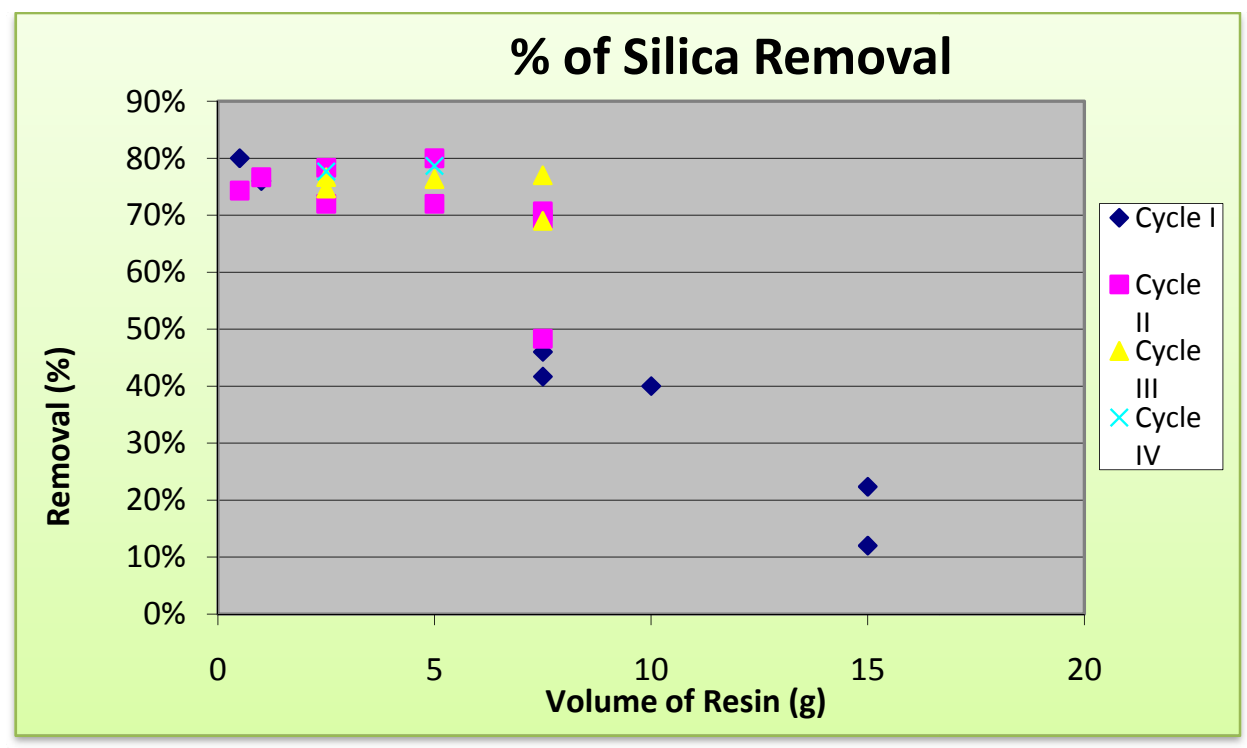

Figure 4.7 - Percentages Amount of silica removal from a synthetic solution using anionic resin (batch test) 
Overall results for these series of equilibrium tests indicated that the effectiveness of ion exchange for silica removal need $\mathrm{pH}$ controlled conditions. Since the results for silica removal under the initial conditions were not as expected, new series of tests were performed under controlled $\mathrm{pH}$ conditions. As reported by Ben Sik Ali et al [6] equilibrium tests may be improved if the resin is previously preconditioned by increasing $\mathrm{pH}[6]$.

\subsubsection{Effect of $\mathrm{pH}$ in the efficiency of silica removal using ionic exchange}

New series of tests were developed adjusting the $\mathrm{pH}$ with $0.1 \mathrm{M}$ of $\mathrm{NaOH}$ or $\mathrm{H}_{2} \mathrm{~S}_{4}$ solutions, and using the same technique for the equilibrium capacity study. For these tests, three $50 \mathrm{~mL}$ tubes were filled with aliquots of silica solution. In two of them, the same amount of resin was added and the third one was used as a control sample.

The results are summarized in Table 4.12. In this table the weight of resin per milliliter of solution is included in column III, the mass in column (IX), and the relationship between the mass sorbed per mass of resin is reported in column (XI). This table shows that at $\mathrm{pH}$ values higher than 10 ,

the ration of silica removed: resin was in the order of $1 \times 10^{-3}$, and the percentages removed were around $50 \%$. These results suggest that at $\mathrm{pH}>10$, silica can be effectively removed from water using resin Dowex $21 \mathrm{~K}$ XLT. The decision to use this technique for silica removal from brines requires an economical evaluation that is beyond the scope of this work. 
Table 4.7 - Results for silica removal from a synthetic solution and anionic resin Dowex $21 \mathrm{~K}$ XLT at different $\mathrm{pH}$ values

\begin{tabular}{|c|c|c|c|c|c|c|c|c|c|c|}
\hline $\begin{array}{c}\text { (I) } \\
\text { Sample }\end{array}$ & $\begin{array}{c}\text { (II) } \\
\text { Water } \\
\text { volume } \\
(\mathrm{mL})\end{array}$ & $\begin{array}{c}\text { (III) } \\
\text { Weigh } \\
\text { of resin } \\
\text { (g) }\end{array}$ & $\begin{array}{l}\text { (IV) } \\
\text { (m) } \\
\text { (g/l) }\end{array}$ & $\begin{array}{l}\text { (V) } \\
\text { pH }\end{array}$ & $\begin{array}{c}\text { (VI) } \\
\text { Initial } \\
\mathrm{SiO}_{2} \\
(\mathrm{mg} / \mathrm{L})\end{array}$ & $\begin{array}{c}\text { (VII) } \\
\text { Final } \\
\mathrm{SiO}_{2} \\
(\mathrm{mg} / \mathrm{L})\end{array}$ & $\begin{array}{c}\text { (VIII) } \\
\mathrm{SiO}_{2} \\
\text { removal } \\
\text { (g) }\end{array}$ & $\begin{array}{c}\text { (IX) } \\
\text { (x) }\end{array}$ & $\begin{array}{c}(\mathrm{X}) \\
\mathrm{SiO}_{2} \\
\text { removal } \\
\%\end{array}$ & $\begin{array}{c}(\mathrm{XI}) \\
\mathrm{X}=\mathrm{X} / \mathrm{m}\end{array}$ \\
\hline 1 & 50 & 1.03 & 20.6 & 11.1 & 32.9 & 16.1 & $8.40 \mathrm{E}-04$ & 0.0168 & 51.06 & $8.16 \mathrm{E}-04$ \\
\hline 2 & 50 & 1.04 & 20.8 & 11.1 & 32.9 & 15.7 & $8.60 \mathrm{E}-04$ & 0.0172 & 52.28 & $8.27 \mathrm{E}-04$ \\
\hline 3 & 50 & 0 & 0 & 11.1 & 32.9 & 32.9 & 0 & & 0 & \\
\hline 4 & 50 & 1.04 & 20.8 & 10.29 & 32.1 & 15.5 & $8.30 \mathrm{E}-04$ & 0.0166 & 51.71 & $7.98 \mathrm{E}-04$ \\
\hline 5 & 50 & 1.04 & 20.8 & 10.29 & 32.1 & 14.9 & $8.60 \mathrm{E}-04$ & 0.0172 & 53.58 & $8.27 \mathrm{E}-04$ \\
\hline 6 & 50 & 0 & 0 & 10.29 & 32.1 & 32.1 & 0 & & 0 & \\
\hline 7 & 50 & 1.04 & 20.8 & 9.22 & 31.7 & 30.2 & $7.50 \mathrm{E}-05$ & 0.0015 & 4.73 & $7.21 \mathrm{E}-05$ \\
\hline 8 & 50 & 1.04 & 20.8 & 9.22 & 31.7 & 29.2 & $1.25 \mathrm{E}-04$ & 0.0025 & 7.89 & $1.20 \mathrm{E}-04$ \\
\hline 9 & 50 & 0 & 0 & 9.22 & 31.7 & 31.7 & 0 & & 0 & \\
\hline 10 & 50 & 1.04 & 20.8 & 8.52 & 32.1 & 30.7 & $7.00 \mathrm{E}-05$ & 0.0014 & 4.36 & $6.73 \mathrm{E}-05$ \\
\hline 11 & 50 & 1.04 & 20.8 & 8.52 & 32.1 & 31.6 & $2.50 \mathrm{E}-05$ & 0.0005 & 1.56 & $2.40 \mathrm{E}-05$ \\
\hline 12 & 50 & 0 & 0 & 8.52 & 32.1 & 32.1 & 0 & & 0 & \\
\hline 13 & 50 & 1.04 & 20.8 & 7.61 & 29.8 & 29.7 & $5.00 \mathrm{E}-06$ & 0.0001 & 0.34 & $4.81 \mathrm{E}-06$ \\
\hline 14 & 50 & 1.04 & 20.8 & 7.61 & 29.8 & 29.8 & 0 & 0 & 0 & 0 \\
\hline 15 & 50 & 0 & 0 & 7.61 & 29.8 & 29.8 & 0 & & 0 & \\
\hline 16 & 50 & 1.04 & 20.8 & 6.28 & 29.6 & 29.5 & $5.00 \mathrm{E}-06$ & 0.0001 & 0.34 & $4.81 \mathrm{E}-06$ \\
\hline 17 & 50 & 1.04 & 20.8 & 6.28 & 29.6 & 29.4 & $1.00 \mathrm{E}-05$ & 0.0002 & 0.68 & $9.62 \mathrm{E}-06$ \\
\hline 18 & 50 & 0 & 0 & 6.28 & 29.6 & 29.6 & 0 & & 0 & \\
\hline 19 & 50 & 1.04 & 20.8 & 5.41 & 30.3 & 29.5 & $4.00 \mathrm{E}-05$ & 0.0008 & 2.64 & $3.85 \mathrm{E}-05$ \\
\hline 20 & 50 & 1.04 & 20.8 & 5.41 & 30.3 & 30.2 & $5.00 \mathrm{E}-06$ & 0.0001 & 0.33 & $4.81 \mathrm{E}-06$ \\
\hline 21 & 50 & 0 & 0 & 5.41 & 30.3 & 30.3 & 0 & & 0 & \\
\hline 22 & 50 & 1.04 & 20.8 & 3.27 & 26.5 & 26.5 & 0 & 0 & 0 & 0 \\
\hline 23 & 50 & 1.04 & 20.8 & 3.27 & 26.5 & 26.5 & 0 & 0 & 0 & 0 \\
\hline 24 & 50 & 0 & 0 & 3.27 & 26.5 & 26.5 & 0 & & 0 & \\
\hline
\end{tabular}




\subsection{Test for Silica Removal Using an ANionic EXChange Column}

\subsubsection{Silica removal from a synthetic solution using an ionic exchange column}

Results for silica removal using the resin Dowex 21K XLT under flow conditions are shown in Table 4.8. As shown in this table, the highest removal (73\%) was obtained at a flow rate of $2.9 \mathrm{~mL} / \mathrm{min}$ after $175 \mathrm{~min}$. By the time when the breakthrough occurred, approximately $50 \%$ of the total content of silica was removed. Taking into consideration the $\mathrm{pKa}$ of the silicic acid and the $\mathrm{pH}$ of the solution (8.5), the percent of ion $\left[\mathrm{H}_{3} \mathrm{SiO}_{4}\right]^{-}$present in solution may be similar to the percent of silica removed.

Silica dissolved in water creates the monosilicic acid $\left(\mathrm{H}_{4} \mathrm{SiO}_{4}\right)$ as shown in Equation 4.1

$$
\mathrm{SiO}_{2}+2 \mathrm{H}_{2} \mathrm{O} \rightarrow \mathrm{H}_{4} \mathrm{SiO}_{4}
$$

In this form, silica is generally un-ionized at most natural $\mathrm{pH}$ levels. At $\mathrm{pH} 8.5$, only $10 \%$ of the monosilicic acid is ionized, and if the $\mathrm{pH}$ reaches 9 to 10 , only $50 \%$ of the monosilicic acid is ionized (Equation 4.2).

$$
\mathrm{pKa}=\frac{\left[\mathrm{H}_{3} \mathrm{SiO}_{4}\right]\left[\mathrm{H}^{+}\right]}{\left[\mathrm{H}_{4} \mathrm{SiO}_{4}\right]}=9.9 *
$$

*concentration dependent

The data sheet for the anionic resin reports an interchange capacity of 1.3 equivalents of silica per liter of resin. Assuming that only $10 \%$ of the $\mathrm{SiO}_{2}$ can be removed by the anionic resin, the theoretical amount of this compound silica to be removed is 0.13 equivalents per liter of resin. This value corresponds to 7.8 grams per 1 liter of resin. In this experiment the amount of resin used was $29.4 \mathrm{~mL}$; thus the amount of silica that can be theoretically removed is $(29.4 / 1000)(7.8)=0.23$ grams $=230$ milligrams. The total silica removed by this test was $13.64 \mathrm{mg}$. Taking in account that the $\mathrm{SiO}_{2}$ content in solution was $22.2 \mathrm{mg}(0.562 \mathrm{~L} \times 39.5 \mathrm{mg} / \mathrm{L})$, the efficiency of this process was $62.2 \%[(13.64) /(22.2)$ $100=62.2]$ 
Table 4.8 - Results for silica removal from a synthetic solution using anionic resin Dowex $21 \mathrm{~K}$ XLT under flow conditions

\begin{tabular}{|c|c|c|c|c|c|c|}
\hline Time & Volume & Flow & $\begin{array}{c}\mathrm{SiO}_{2} \\
\text { initial }\end{array}$ & $\begin{array}{c}\mathrm{SiO}_{2} \\
\text { final }\end{array}$ & Variation. & $\begin{array}{c}\text { Amount of } \\
\text { Silica } \\
\text { removed }\end{array}$ \\
\hline$(\mathrm{min})$ & $(\mathrm{mL})$ & $(\mathrm{mL} / \mathrm{min})$ & $\mathrm{mg} / \mathrm{L}$ & $\mathrm{mg} / \mathrm{L}$ & & $\mathrm{mg}$ \\
\hline 0 & 0 & 0 & 39.5 & & & \\
\hline 25 & 45 & 1.80 & 39.5 & 12.7 & 26.8 & 1.21 \\
\hline 35 & 25 & 2.50 & 39.5 & 11.6 & 27.9 & 0.70 \\
\hline 45 & 28 & 2.80 & 39.5 & 15.4 & 24.1 & 0.67 \\
\hline 55 & 25 & 2.50 & 39.5 & 19.4 & 20.1 & 0.50 \\
\hline 65 & 26 & 2.60 & 39.5 & 19.5 & 20 & 0.52 \\
\hline 75 & 25 & 2.50 & 39.5 & 16.6 & 22.9 & 0.57 \\
\hline 85 & 25 & 2.50 & 39.5 & 14.5 & 25 & 0.63 \\
\hline 95 & 27 & 2.70 & 39.5 & 13.1 & 26.4 & 0.71 \\
\hline 105 & 26 & 2.60 & 39.5 & 12.2 & 27.3 & 0.71 \\
\hline 118 & 25 & 1.92 & 39.5 & 11.5 & 28 & 0.70 \\
\hline 130 & 25 & 2.08 & 39.5 & 11.5 & 28 & 0.70 \\
\hline 140 & 25 & 2.50 & 39.5 & 12.2 & 27.3 & 0.68 \\
\hline 152 & 25 & 2.08 & 39.5 & 11.7 & 27.8 & 0.70 \\
\hline 165 & 25 & 1.92 & 39.5 & 12.7 & 26.8 & 0.67 \\
\hline 175 & 29 & 2.90 & 39.5 & 10.4 & 29.1 & 0.84 \\
\hline 182 & 26 & 3.71 & 39.5 & 12.6 & 26.9 & 0.70 \\
\hline 188 & 30 & 5.00 & 39.5 & 16.5 & 23 & 0.69 \\
\hline 194 & 25 & 4.17 & 39.5 & 19.5 & 20 & 0.50 \\
\hline 199 & 25 & 5.00 & 39.5 & 22.0 & 17.5 & 0.44 \\
\hline 205 & 25 & 4.17 & 39.5 & 21.6 & 17.9 & 0.44 \\
\hline 211 & 25 & 4.17 & 39.5 & 25.4 & 14.9 & 0.45 \\
\hline & & & & & & \\
\hline
\end{tabular}

The percent of silica removed $(62.2 \%)$ could be explained by the kinetic of the dissociation of the silicic acid. By the time the breakthrough occurred, the amount of ions $\left[\mathrm{H}_{3} \mathrm{SiO}_{4}\right]^{-}$in solution was very low, and the velocity of the dissociation was not high enough to compensate the equilibrium of ions attached to the resin and ions in solution. Even though the resin had enough capacity to accept more $\left[\mathrm{H}_{3} \mathrm{SiO}_{4}\right]^{-}$, it is hypothesized that the amount of ions in solution was not high enough to fill all the binding sites.

Additional tests were performed using similar conditions, but with the concentrate of the nanofiltration plant. As previously stated, the solution $\mathrm{pH}$ could not be raised higher than 8.5 without observing calcium and magnesium precipitation. Tests carried out, at $\mathrm{pH}$ values ranging from 8.2 to 8.5 showed low silica removal efficiency. Wilmarth et al. [11] working under similar conditions, reported a 
low efficiency for quaternary ammonium resins. Additional research is needed to analyze the best conditions for silica removal besides increasing the $\mathrm{pH}$ value.

\subsubsection{Silica removal from the concentrate of a nano filtration plant using an IE column}

In order to determine the efficiency of the anionic column for silica removal from the concentrate of the nano-filtration plant, an experiment was carried out using an initial silica concentration of $153.6 \mathrm{mg} / \mathrm{L}$. The sample had a $\mathrm{pH}$ of 8.08 and a total hardness of $730 \mathrm{mg} / \mathrm{L} .15 \mathrm{~g}$ of Dowex $21 \mathrm{KXLT}$ anionic exchange resin were used under an average ascendant flow of $3.5 \mathrm{~mL} / \mathrm{min}$. The results are reported in the Table 4.9.

Table 4.9 - Results for silica removal from a concentrate of a NFPP using anionic resin Dowex 21 K XLT under flow conditions

\begin{tabular}{|c|c|c|c|c|c|}
\hline $\begin{array}{c}\text { Volume } \\
(\mathrm{mL})\end{array}$ & $\begin{array}{c}\text { Flow } \\
(\mathrm{mL} / \mathrm{min})\end{array}$ & $\mathrm{SiO}_{2}$ initial & $\mathrm{SiO}_{2}$ final & Variation. & $\begin{array}{c}\text { Amount of silica } \\
\text { removed (mg) }\end{array}$ \\
\hline 25 & 3.5 & 153.6 & 87.2 & 66.4 & 1.66 \\
\hline 50 & 3.5 & 153.6 & 119.8 & 33.8 & 0.85 \\
\hline 75 & 3.5 & 153.6 & 134.8 & 18.8 & 0.47 \\
\hline 100 & 3.5 & 153.6 & 135.6 & 18.0 & 0.45 \\
\hline 125 & 3.5 & 153.6 & 138.4 & 15.2 & 0.38 \\
\hline 150 & 3.5 & 153.6 & 140.6 & 13.0 & 0.33 \\
\hline 175 & 3.5 & 153.6 & 150.4 & 3.2 & 0.08 \\
\hline 200 & 3.5 & 153.6 & 153.6 & 0.0 & 0.00 \\
\hline
\end{tabular}

The data showed a total removal of $4.2 \mathrm{mg}$ of silica and a ratio of $0.281 \times 10^{-3} \mathrm{~g}$ silica per $\mathrm{g}$ of resin. The mass of silica in solution was calculated using the volume and the concentration of silica in solution; this was found to be $200 \mathrm{~mL} \times 153.6 \mathrm{mg} / 1000 \mathrm{~mL}=30.7 \mathrm{mg}$.

The removal efficiency was calculated using the mass of silica removed and the mass in solution. As shown below, the efficiency was $13.7 \%$. This value is low and should be economically evaluated to be considered for an industrial process. 


$$
\text { Removal efficiency }=[(4.2) /(30.7] \times 100=13.7 \%
$$

Since the $\mathrm{pH}$ value for this experiment (8.08) was lower than the one described in the previous section (8.5), it was expected that less ions would be present in the solution and, therefore lower efficiency was also expected. Additionally the presence of other anions such as sulfates and chlorides, with higher affinity to the resin, limited the removal of ions $\left[\mathrm{H}_{3} \mathrm{SiO}_{4}\right]^{-}$. In this experiment, the removal of silica was almost negligible after an effluent of $200 \mathrm{~mL}$.

\subsection{HARDNESS REMOVAL}

\subsubsection{Hardness removal from a nano-filtration concentrate using cationic resin Bayer Ionac C- 249 under flow conditions}

Results for hardness removal from the concentrate of the NFPP using cationic resin are shown in Table 4.10. As shown in this table, the total hardness removal calculated using a flow rate of $20 \mathrm{~mL} / \mathrm{min}$ was $1,042 \mathrm{mg}$ that represents a hardness removal efficiency of $51 \%$. Efficiency was calculated using the total amount of hardness in solution $(2,035 \mathrm{mg})$ and the hardness removed, as shown below

$$
\text { Efficiency removal }=((1,042) /(2,035)) 100=51 \%
$$

The final hardness concentration of treated water can be controlled by managing the breakthrough point for the process or adjusting the flow rate.

For the test reported in Appendix B, Table B.2, the removal efficiency was $66 \%$ using a flow rate of $11 \mathrm{~mL} / \mathrm{min}$. It can be observed that the breakthrough, under lower flow conditions, as is the case of the experiment shown in Table 4.10 was reached after more time (about 100 minutes) than the corresponding for this test (about $50 \mathrm{~min}$ ), in which the flow rate was higher.

For both tests, in order to obtain any desired hardness, the efficiency can be improved by controlling the flow rate and the final breakthrough point, before the resin regeneration. 
Table 4.10 - Results for hardness removal from a nano-filtration concentrate using cationic resin Bayer Ionac C-249 under flow conditions

\begin{tabular}{|c|c|c|c|c|c|c|}
\hline Time & Volume & Flow & $\begin{array}{c}\text { Hardness } \\
\text { initial }\end{array}$ & $\begin{array}{c}\text { Hardness } \\
\text { final }\end{array}$ & Variation. & $\begin{array}{c}\text { Amount } \\
\text { of } \\
\text { Hardness } \\
\text { removed }\end{array}$ \\
\hline$(\mathrm{min})$ & $(\mathrm{mL})$ & $(\mathrm{mL} / \mathrm{min})$ & $\mathrm{mg} / \mathrm{L}$ & $\mathrm{mg} / \mathrm{L}$ & & $\mathrm{mg}$ \\
\hline 0 & 0 & 0 & 690 & & & \\
\hline 12.5 & 250 & 20 & 690 & 10 & 680 & 170.00 \\
\hline 25.0 & 250 & 20 & 690 & 35 & 655 & 163.75 \\
\hline 27.5 & 50 & 20 & 690 & 50 & 640 & 32.00 \\
\hline 30.0 & 50 & 20 & 690 & 55 & 635 & 31.75 \\
\hline 32.5 & 50 & 20 & 690 & 60 & 630 & 31.50 \\
\hline 35.0 & 50 & 20 & 690 & 65 & 625 & 31.25 \\
\hline 37.5 & 50 & 20 & 690 & 80 & 610 & 30.50 \\
\hline 42.5 & 100 & 20 & 690 & 100 & 590 & 59.00 \\
\hline 47.5 & 100 & 20 & 690 & 110 & 580 & 58.00 \\
\hline 60.0 & 250 & 20 & 690 & 170 & 520 & 130.00 \\
\hline 72.5 & 250 & 20 & 690 & 265 & 425 & 106.25 \\
\hline 85.0 & 250 & 20 & 690 & 380 & 310 & 77.50 \\
\hline 97.5 & 250 & 20 & 690 & 470 & 220 & 55.00 \\
\hline 110.0 & 250 & 20 & 690 & 580 & 110 & 27.50 \\
\hline 122.5 & 250 & 20 & 690 & 600 & 90 & 22.50 \\
\hline 135.0 & 250 & 20 & 690 & 640 & 50 & 12.50 \\
\hline 147.5 & 250 & 20 & 690 & 680 & 10 & 2.50 \\
\hline
\end{tabular}

As part of this research, salt with high $\mathrm{Na}$ content, recovered from evaporation ponds for brine disposal alternatives, was tested for cationic resin regeneration.

Results show that salt treatment regenerated the resin after 30 bed volumes (Appendix B, Table B.3). As mentioned above, this may be an option to make these processes "environmentally friendly". 


\subsubsection{Equilibrium tests}

Equilibrium test were performed for hardness removal, using cationic resins. Results are shown in Table 4.11

Table 4.11 - - Equilibrium test results for hardness removal

\begin{tabular}{|c|c|c|c|c|c|c|c|c|}
\hline \multicolumn{7}{|c|}{ Test for Concentrate Treated With Cationic Resin } \\
\hline mass of resin & Humidity & dry mass $(\mathbf{m})$ & volume & $\mathbf{m}$ & $\mathbf{C o}$ & $\mathbf{C e}$ & Delta C, $\mathbf{x}$ & $\mathbf{X}=\mathbf{x} / \mathbf{m}$ \\
\hline $\mathbf{g}$ & $\mathbf{\%}$ & $\mathbf{g}$ & $\mathbf{L}$ & $\mathbf{g} / \mathbf{L}$ & $\mathbf{g} / \mathbf{L}$ & $\mathbf{g} / \mathbf{L}$ & $\mathbf{g} / \mathbf{L}$ & $\mathbf{g} / \mathbf{g}$ \\
\hline \hline & & & & & & & & \\
\hline 0.050 & 50.00 & 0.025 & 0.050 & 0.500 & 0.690 & 0.530 & 0.160 & 0.320 \\
\hline 0.230 & 50.00 & 0.115 & 0.050 & 2.289 & 0.690 & 0.260 & 0.430 & 0.188 \\
\hline 0.370 & 50.00 & 0.185 & 0.050 & 3.673 & 0.690 & 0.160 & 0.530 & 0.144 \\
\hline 0.490 & 50.00 & 0.245 & 0.050 & 4.852 & 0.690 & 0.120 & 0.570 & 0.117 \\
\hline 0.890 & 50.00 & 0.445 & 0.051 & 8.744 & 0.690 & 0.060 & 0.630 & 0.072 \\
\hline 1.070 & 50.00 & 0.535 & 0.051 & 10.476 & 0.690 & 0.045 & 0.645 & 0.062 \\
\hline 1.430 & 50.00 & 0.715 & 0.051 & 13.902 & 0.690 & 0.030 & 0.660 & 0.047 \\
\hline
\end{tabular}

The relationship between the equilibrium concentration and the amount of hardness removed by the resin was evaluated using the Freundlich equation

$$
\frac{x}{m}=X=\mathrm{KC}_{\mathrm{e}}{ }^{1 / \mathrm{n}}
$$

where:

$\mathrm{x}=\quad$ mass of solute adsorbed

$\mathrm{m}=\quad$ mass of adsorbent

$\mathrm{X}=\quad$ mass ratio of the solid phase - that is, the mass of adsorbed solute per mass of adsorbent

$\mathrm{C}_{\mathrm{e}}=\quad$ equilibrium concentration of solute, mass/volume

$\mathrm{K}, \mathrm{n}=$ experimental constants.

This equation can be converted to a linear equation by using logarithms, thus the equation 4.3 is transformed to:

$$
\log \frac{x}{m}=\log K+\frac{1}{n} \log C_{\mathrm{e}}
$$


The graphical representation of the equation 4.4 is identified as a Freundlich isotherm. In this graph, the value of " $\mathrm{n}$ " is obtained by the slope of the line; " $\mathrm{K}$ " is the value of the intersection of the line with the y axis.

Experimental values are shown in the Figure 4.17

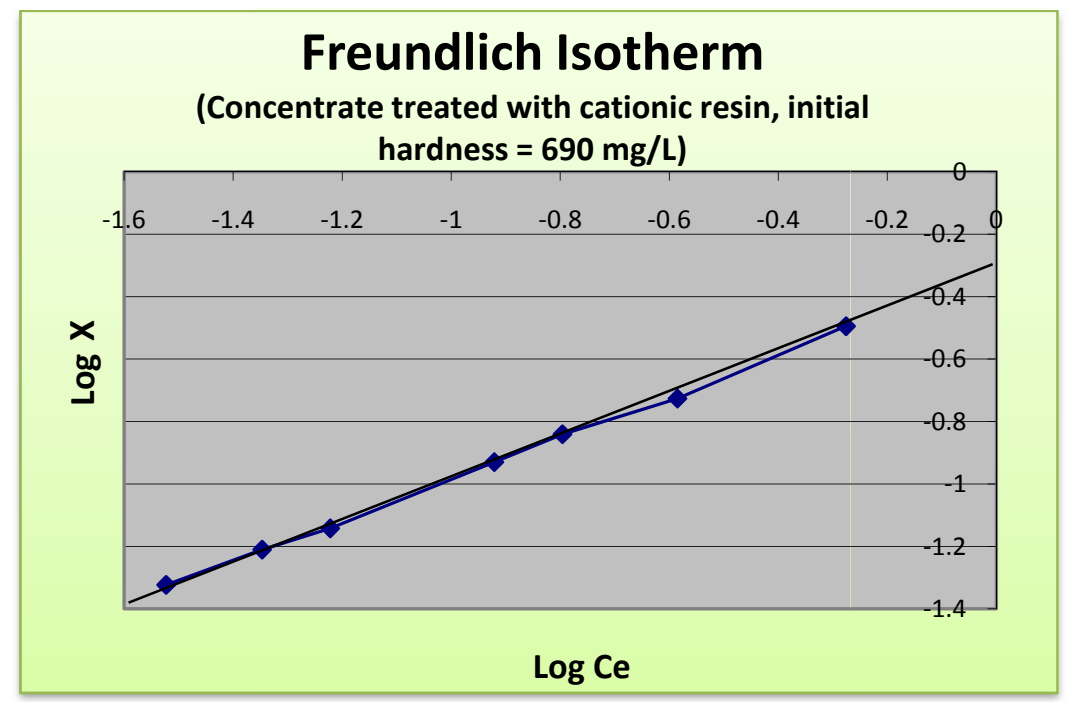

Figure 4.8 - Freundlich Isotherm (Cationic resin and concentrate).

Final equation for the ion exchange of this solution and the cationic resin is:

$$
\frac{x}{m}=X=0.464 \mathrm{C}_{\mathrm{e}}^{1 / 1.587}
$$

The calculated correlation for the points in the figure is: 0.999 ; therefore, the results have an almost perfect match to the Freundlich equation. 


\section{Chapter 5: Conclusions}

The results of this research has corroborated that the effectiveness for silica removal using ion exchange resins highly depends on $\mathrm{pH}$. Monosilicic acid most be dissociated to release the silica and this only effectively happens at $\mathrm{pH}$ values higher than 9.0.

The presence of anions with higher affinity for the quaternary-ammonium resins affects silica removal.

Dowex 21K XLT and Dowex Marathon MSA resins showed similar behavior for silica removal.

In the case of the silica removal from the concentrate of the nano-filtration pilot plant, which contained high concentrations of calcium and magnesium, $\mathrm{pH}$ increase was not feasible because the calcium and magnesium precipitate as insoluble hydroxides. These precipitates physically interfered in the ion exchange process, clogging the resin column.

Results have shown that high values of hardness, calcium, magnesium and even barium must be removed before the removal of silica from brine. This can be done by precipitation using lime or sodium hydroxide to increase the $\mathrm{pH}$, thus precipitating the carbonates and hydroxides, or using a cationic exchange process.

Positive results were obtained for hardness removal from the concentrate of the NFPP using the cationic exchange resins Dowex G-26 and Bayer Ionac C-249.

Additional work needs to be developed in order to make a mass balance for the process described above and determine the economic feasibility for this process, comparing the process cost and the cost for disposal of the additional un-recovered water.

Recovered salt from the brine evaporation process can be used to regenerate the exhausted resin, making the process environmental friendly (See Appendix B).

Additional research is needed to test the effectiveness for silica removal from this concentrate using a combined process of cationic exchange, $\mathrm{pH}$ increase, and anionic exchange (See Appendix B). 


\section{References}

[1] Kunin Robert, The Role of Silica in Water Treatment, Amber-hi-lites No. 164, summer 1980.

[2] Walter Den and Wang Chia-Jung, Removal of Silica from Brackish Water by Electrocoagulation Pretreatment to Prevent Fouling of Reverse Osmosis Membranes, Separation and Purification Technology 59 (2008) 318-325

[3] Ning Robert Y, Discussion of silica speciation, fouling, control and maximum reduction, Desalination 151 (2002) 67-73

[4] R.K Iler, The Chemistry of Silica, John Wiley and Sons, New York, N.Y. (1979).

[5] Broderick Gene, Taylor Duane, Stopping Silica with Whole-House RO, Water Technology magazine, (August 1995)

[6] Ben Sik Ali M., Hamrouni B., Bouguecha S., Dhahbi M., Silica removal using ion-exchange resins, Desalination 167 (2004) 273-279

[7] Mebrure Badruk, Matsunagab Isao, Experimental Results of Silica Removal from Simulated Solutions of Geothermal Brine of Kizildere field, Turkey. Geothermics 30 (2001) 561-570

[8] Meyers Peter, Behavior of Silica in Ion Exchange and Other Systems (1999), ResinTech Inc. IWC-99-64

[9] Gallup Darrell L, Investigations of Organic Inhibitors for Silica Scale Control in Geothermal Brines, Geothermics, 31(2002) 415-430

[10] Bremerea Ingrida, Kennedya Maria, Mhyioa Sahar, Jaljuli Abdulfattah, Witkamp Geert-Jan, and Schippers Jan, Prevention of Silica Scale in Membrane Systems: Removal of Monomer and Polymer Silica, Desalination 132 (2000) 89-100

[11] Wilmarth W. R., Mills J. T., and Dukes V. H., Silicon Removal from Waste Simulants via Ion Exchange, (2002) Aiken, SC: Westinghouse Savannah River Company/ U.S. Department of Energy.

[12] Reynolds Tom D and Richards Paul A, Unit Operation and Processes in Environmental Engineering, Second Edition (1999), International Thomson Publishing 


\section{Appendix A}

\section{A.1-SILICA REMOVAL REPORT}

\section{A.1.1-Silica removal from prepared solutions of $\mathrm{SiO}_{2}$}

\section{Experiment A.1}

A silica solution was prepared with deionized RO water and sodium metasilicate to obtain a concentration of $40 \mathrm{mg} / \mathrm{L}$ of silica. The $\mathrm{pH}$ was adjusted to 8.5 using sodium hydroxide. A glass tube was filled with quaternary ammonium anionic resin to make an anionic exchange column. The minimum recommend height for the column was $80 \mathrm{~cm}$. The resin was washed with deionized RO water before the beginning the test. The characteristics of the column are summarized in Table A.1.

\section{Table A.1 -Anionic exchange column characteristics}

\begin{tabular}{|l|c|}
\hline \multicolumn{2}{|c|}{ Anionic Exchange Column } \\
\hline $\begin{array}{l}\text { Anionic exchange resin } \\
\text { volume }\end{array}$ & $29.4 \mathrm{~mL}$ \\
\hline Column diameter & $0.604 \mathrm{~cm}$. \\
\hline Bed height & $102.5 \mathrm{~cm}$. \\
\hline $\begin{array}{l}\text { Detention time with void } \\
\text { bed }\end{array}$ & $8.9 \mathrm{~min}$ \\
\hline Average flow & $3.3 \mathrm{~mL} / \mathrm{min}$ \\
\hline Type of flow & Ascendant \\
\hline Resin & Dowex 21KXLT \\
\hline
\end{tabular}

Flow rates from 1.9 to 4.2 were adjusted using a peristaltic pump. Silica concentration and the net amounts of silica removed were reported in the Table A.2. 
Table A.2- Silica removal results using an ionic exchange column and anionic resin

\begin{tabular}{|c|c|c|c|c|c|c|}
\hline Time & Volume & Flow & $\begin{array}{c}\mathrm{SiO} 2 \\
\text { initial }\end{array}$ & $\begin{array}{c}\text { Si02 } \\
\text { final }\end{array}$ & Variation. & $\begin{array}{c}\text { Amount of } \\
\text { Silica } \\
\text { removed }\end{array}$ \\
\hline$(\mathrm{min})$ & $(\mathrm{mL})$ & $(\mathrm{mL} / \mathrm{min})$ & $\mathrm{mg} / \mathrm{L}$ & $\mathrm{mg} / \mathrm{L}$ & & $\mathrm{mg}$ \\
\hline 0 & 0 & 0 & 39.5 & & & \\
\hline 13 & 25 & 1.92 & 39.5 & 11.5 & 28.0 & 0.70 \\
\hline 12 & 25 & 2.08 & 39.5 & 11.5 & 28.0 & 0.70 \\
\hline 10 & 25 & 2.50 & 39.5 & 12.2 & 27.3 & 0.68 \\
\hline 12 & 25 & 2.08 & 39.5 & 11.7 & 27.8 & 0.70 \\
\hline 13 & 25 & 1.92 & 39.5 & 12.7 & 26.8 & 0.67 \\
\hline 10 & 29 & 2.90 & 39.5 & 10.4 & 29.1 & 0.84 \\
\hline 7 & 26 & 3.71 & 39.5 & 12.6 & 26.9 & 0.70 \\
\hline 6 & 30 & 5.00 & 39.5 & 16.5 & 23.0 & 0.69 \\
\hline 6 & 25 & 4.17 & 39.5 & 19.5 & 20.0 & 0.50 \\
\hline 5 & 25 & 5.00 & 39.5 & 22.0 & 17.5 & 0.44 \\
\hline 6 & 25 & 4.17 & 39.5 & 21.6 & 17.9 & 0.45 \\
\hline 6 & 25 & 4.17 & 39.5 & 25.4 & 14.1 & 0.35 \\
\hline
\end{tabular}

Results showed that the lowest value of silica concentration was 10.4 , equivalent to $73 \%$ of the initial silica content. The total amount of silica removed was calculated adding the corresponding amounts from each sample. It is assumed that only $10 \%$ of the $\mathrm{SiO}_{2}$ dissociate at $\mathrm{pH} 8.5$

The total amount of silica removed in this experiment was $7.42 \mathrm{mg}$, while the total amount of silica in the solution was $12.24 \mathrm{mg}$. The calculated efficiency was

$$
\text { Removal efficiency }=((7.42) /(12.24)) 100=61 \%
$$

\section{A.1.2-Silica removal from a concentrate from a nano-filtration pilot plant using anionic resin Dowex 21 K XLT}

Experiment A.2

A concentrated solution from the nano-permeate pilot plant was treated with cationic resin to reduce the hardness to $15 \mathrm{mg} / \mathrm{L}$. The solution had a concentration of $146 \mathrm{mg} / \mathrm{L}$ of silica after the hardness removal. The $\mathrm{pH}$ was adjusted to 10.79 from an original value of 8.08 using sodium hydroxide. A glass tube was filled with quaternary ammonium anionic resin (Dowex $21 \mathrm{KXLT}$ ) to make an anionic 
exchange column. The resin was washed with deionized RO water before beginning the test. The characteristics of the column are summarized in Table A.3

Table A.3- Anionic exchange column characteristics

\begin{tabular}{|l|c|}
\hline \multicolumn{2}{|c|}{ Anionic Exchange Column } \\
\hline $\begin{array}{l}\text { Anionic exchange resin } \\
\text { apparent volume }\end{array}$ & $14 \mathrm{~mL}$ \\
\hline $\begin{array}{l}\text { Anionic exchange resin } \\
\text { weight (g) }\end{array}$ & 11.15 \\
\hline Column diameter & $0.541 \mathrm{~cm}$. \\
\hline Bed height & $15.2 \mathrm{~cm}$. \\
\hline $\begin{array}{l}\text { Detention time with void } \\
\text { bed }\end{array}$ & $3.5 \mathrm{~mL} / \mathrm{min}$ \\
\hline Average flow & Ascendant \\
\hline Type of flow & \\
\hline
\end{tabular}

The flow rate was adjusted by gravity to $3.5 \mathrm{~mL} / \mathrm{min}$ and samples were collected every $50 \mathrm{~mL}$. Silica concentration was measured using a spectrophotometer Hach-4000. Silica concentrations and the net amounts of silica removed are shown in Table A.4

Table A.4- Results for silica removal using resin 21 K XLT under flow conditions

\begin{tabular}{|c|c|c|c|c|c|c|}
\hline Time & Volume & Flow & $\begin{array}{c}\mathrm{SiO} 2 \\
\text { initial }\end{array}$ & $\begin{array}{c}\mathrm{Si02} \\
\text { final }\end{array}$ & Variation. & $\begin{array}{c}\text { Amount of } \\
\text { Silica } \\
\text { removed }\end{array}$ \\
\hline$(\mathrm{min})$ & $(\mathrm{mL})$ & $(\mathrm{mL} / \mathrm{min})$ & $\mathrm{mg} / \mathrm{L}$ & $\mathrm{mg} / \mathrm{L}$ & & $\mathrm{mg}$ \\
\hline 0 & 0 & 0 & 146 & & & \\
\hline 14.3 & 50 & 3.5 & 146 & 135.4 & 10.6 & 0.53 \\
\hline 28.6 & 100 & 3.5 & 146 & 136.8 & 9.2 & 0.46 \\
\hline 42.9 & 150 & 3.5 & 146 & 142.6 & 3.4 & 0.17 \\
\hline 57.1 & 200 & 3.5 & 146 & 144.8 & 1.2 & 0.06 \\
\hline 71.4 & 250 & 3.5 & 146 & 146 & 0 & 0 \\
\hline
\end{tabular}

For this test, the total amount of silica removed was $1.22 \mathrm{mg}$, total amount of silica in the solution was $36.5 \mathrm{mg}$ and the efficiency was found to be very poor (3.3\%) 


$$
\text { Removal efficiency }=((1.22) /(36.5)) 100=3.3 \%
$$

\section{Experiment A.3}

A concentrated solution from the nano-permeate pilot plant was treated with cationic resin to reduce the hardness to $40 \mathrm{mg} / \mathrm{L}$. The solution had a concentration of $149 \mathrm{mg} / \mathrm{L}$ of silica after hardness removal. The $\mathrm{pH}$ was adjusted to 10.16 from an original value of 8.47 using sodium hydroxide. A glass tube was filled with quaternary ammonium anionic resin (Dowex Marathon MSA) to make an anionic exchange column. The resin was washed with deionized RO water before beginning the test. The characteristics of the column are summarized in Table A.5

\section{Table A.5- Anionic exchange column characteristics}

\begin{tabular}{|l|c|}
\hline \multicolumn{2}{|c|}{ Anionic Exchange Column } \\
\hline $\begin{array}{l}\text { Anionic exchange resin } \\
\text { apparent volume }\end{array}$ & $25 \mathrm{~mL}$ \\
\hline $\begin{array}{l}\text { Anionic exchange resin } \\
\text { weight (g) }\end{array}$ & 15 \\
\hline Column diameter & $0.541 \mathrm{~cm}$. \\
\hline Bed height & $15.2 \mathrm{~cm}$. \\
\hline $\begin{array}{l}\text { Detention time with void } \\
\text { bed }\end{array}$ & $3.3 \mathrm{~mL} / \mathrm{min}$ \\
\hline Average flow & Ascendant \\
\hline Type of flow & \\
\hline
\end{tabular}

The flow rate was adjusted by gravity to $3.3 \mathrm{~mL} / \mathrm{min}$ and samples were collected every $25 \mathrm{~mL}$. Silica concentrations were measured using a spectrophotometer Hach-DR4000U. Silica concentrations and the net amounts of silica removed were reported in the Table A.6. 
Table A.6- Silica removal results using an ionic exchange column and anionic resin

\begin{tabular}{|c|c|c|c|c|c|c|}
\hline Time & Volume & Flow & $\begin{array}{c}\mathrm{SiO}_{2} \\
\text { initial }\end{array}$ & $\begin{array}{c}\mathrm{Si}_{2} \\
\text { final }\end{array}$ & Variation. & $\begin{array}{c}\text { Amount of } \\
\text { Silica } \\
\text { removed }\end{array}$ \\
\hline$(\mathrm{min})$ & $(\mathrm{mL})$ & $(\mathrm{mL} / \mathrm{min})$ & $\mathrm{mg} / \mathrm{L}$ & $\mathrm{mg} / \mathrm{L}$ & & $\mathrm{mg}$ \\
\hline 7.6 & 25 & 3.3 & 149 & 60.4 & 88.6 & 2.22 \\
\hline 15.2 & 50 & 3.3 & 149 & 117 & 32.0 & 0.80 \\
\hline 22.7 & 75 & 3.3 & 149 & 122.2 & 26.8 & 0.67 \\
\hline 30.3 & 100 & 3.3 & 149 & 135 & 14.0 & 0.35 \\
\hline 37.9 & 125 & 3.3 & 149 & 126.4 & 22.6 & 0.57 \\
\hline 45.5 & 150 & 3.3 & 149 & 132.4 & 16.6 & 0.42 \\
\hline 53.0 & 175 & 3.3 & 149 & 129 & 20.0 & 0.50 \\
\hline 60.6 & 200 & 3.3 & 149 & 133.2 & 15.8 & 0.40 \\
\hline 68.2 & 225 & 3.3 & 149 & 134.8 & 14.2 & 0.36 \\
\hline 75.8 & 250 & 3.3 & 149 & 132.2 & 16.8 & 0.42 \\
\hline 83.3 & 275 & 3.3 & 149 & 136.8 & 12.2 & 0.31 \\
\hline
\end{tabular}

For this test, the total amount of silica removed was $7.0 \mathrm{mg}$ and the amount of silica in solution was $41.0 \mathrm{mg}$. The calculated efficiency was $17 \%$.

$$
\text { Efficiency removal }=((7.0) /(41.0)) 100=17 \%
$$




\section{Appendix B}

\section{B.1-HARDNESS REMOVAL REPORT}

\section{B.1.1-Hardness removal from a concentrated solution of a nano-filtration pilot plant}

\section{Experiment B.1}

In this experiment, a cationic resin was used to reduce the hardness of a solution from the NFPP (initial hardness of $690 \mathrm{mg} / \mathrm{L}$ ). A glass tube was filled with the cationic resin Bayer Ionac C-249 to make an ion exchange column. The resin was washed with deionized RO water before beginning the test. The characteristics of the column are summarized in Table B.1

Table B.1 -Anionic exchange column characteristics

\begin{tabular}{|l|c|}
\hline \multicolumn{2}{|c|}{ Anionic Exchange Column } \\
\hline Cationic resin volume & $30 \mathrm{~mL}$ \\
\hline Column diameter & $0.604 \mathrm{~cm}$ \\
\hline Bed height & $104 \mathrm{~cm}$ \\
\hline $\begin{array}{l}\text { Detention time with void } \\
\text { bed }\end{array}$ & $1.49 \mathrm{~min}$ \\
\hline Average flow & $11 \mathrm{~mL} / \mathrm{min}$ \\
\hline Type of flow & Ascendant \\
\hline
\end{tabular}

The flow rate was adjusted to $11 \mathrm{~mL} / \mathrm{min}$ using a peristaltic pump. Samples were collected approximately every $50 \mathrm{~mL}$, and the hardness was measured using the EDTA titrimetic method. Final hardness and the net amounts of hardness removed were reported in the Table B.2. 
Table B.2- Results for hardness removal results using cationic resin Bayer Ionac C-249 under flow conditions

\begin{tabular}{|c|c|c|c|c|c|c|}
\hline Time & Volume & Flow & $\begin{array}{c}\text { Hardness } \\
\text { initial }\end{array}$ & $\begin{array}{c}\text { Hardness } \\
\text { final }\end{array}$ & Variation. & $\begin{array}{c}\text { Amount } \\
\text { of } \\
\text { Hardness } \\
\text { removed }\end{array}$ \\
\hline$(\mathrm{min})$ & $(\mathrm{mL})$ & $(\mathrm{mL} / \mathrm{min})$ & $\mathrm{mg} / \mathrm{L}$ & $\mathrm{mg} / \mathrm{L}$ & & $\mathrm{mg}$ \\
\hline 0 & 0 & 0 & 690 & & & \\
\hline 17.3 & 190 & 11 & 690 & 0 & 690 & 131.1 \\
\hline 35.5 & 200 & 11 & 690 & 0 & 690 & 138.0 \\
\hline 62.7 & 300 & 11 & 690 & 25 & 665 & 199.5 \\
\hline 90.0 & 300 & 11 & 690 & 60 & 630 & 189.0 \\
\hline 127.3 & 410 & 11 & 690 & 140 & 550 & 225.5 \\
\hline 148.2 & 230 & 11 & 690 & 240 & 450 & 103.5 \\
\hline 170.0 & 240 & 11 & 690 & 360 & 330 & 79.2 \\
\hline 191.8 & 240 & 11 & 690 & 460 & 230 & 55.2 \\
\hline 213.6 & 240 & 11 & 690 & 520 & 170 & 40.8 \\
\hline 238.2 & 270 & 11 & 690 & 600 & 90 & 24.3 \\
\hline
\end{tabular}

The total amount of hardness removed (1042 mg) was calculated adding the corresponding amounts of each sample and the removal efficiency (66\%) was calculated as shown below

$$
\text { Efficiency removal }=((1186) /(1808)) 100=66 \%
$$

\section{B.2- CATIONIC RESIN REGENERATION}

\section{Experiment B.2}

The cationic resin Bayer Ionac C-249 was regenerated with a saturated solution of the recovered salt from an evaporation pond containing sodium chloride. The results are reported in Table B.3. 
Table B.3- Regeneration of the cationic resin Bayer Ionac C-249 using recuperated salt from an evaporation pond

\begin{tabular}{|c|c|c|c|c|}
\hline Time & Volume & Flow & Hardness & $\begin{array}{c}\text { Hardness } \\
\text { removed }\end{array}$ \\
\hline$(\mathrm{min})$ & $(\mathrm{mL})$ & $(\mathrm{mL} / \mathrm{min})$ & $\mathrm{mg} / \mathrm{L}$ & $\mathrm{mg}$ \\
\hline 0 & 0 & 0 & & \\
\hline 5.0 & 100 & 20 & 650 & 65.0 \\
\hline 9.5 & 190 & 20 & 4070 & 366.3 \\
\hline 15.5 & 310 & 20 & 1875 & 225.0 \\
\hline 20.5 & 410 & 20 & 1100 & 110.0 \\
\hline 25.5 & 510 & 20 & 750 & 75.0 \\
\hline 35.5 & 710 & 20 & 400 & 80.0 \\
\hline 45.5 & 910 & 20 & 300 & 60.0 \\
\hline 55.5 & 1110 & 20 & 200 & 40.0 \\
\hline 68.0 & 1360 & 20 & 90 & 22.5 \\
\hline 80.5 & 1610 & 20 & 70 & 17.5 \\
\hline 88.0 & 1760 & 20 & 50 & 7.5 \\
\hline 101.0 & 2020 & 20 & 50 & 13.0 \\
\hline 108.5 & 2170 & 20 & 40 & 6.0 \\
\hline 116.0 & 2320 & 20 & 30 & 4.5 \\
\hline 131.0 & 2620 & 20 & 30 & 9.0 \\
\hline 146.0 & 2920 & 20 & 20 & 6.0 \\
\hline
\end{tabular}




\section{Appendix C}

\section{FLOW CALCULATION FOR IONIC EXCHANGE ACCORDING TO THE PRODUCT INFORMATION}

\begin{tabular}{|l|c|c|}
\hline \multicolumn{2}{|c|}{ Flow Calculations } \\
Column 0.604 cm diameter \\
\hline Column height & \multicolumn{2}{c|}{$76 \mathrm{~cm}$} \\
\hline Diameter & \multicolumn{2}{c|}{$0.604 \mathrm{~cm}$} \\
\hline Area & \multicolumn{2}{c|}{$0.287 \mathrm{~cm}^{2}$} \\
\hline Recommended flow & 143.4 & 1721.1 \\
\hline Equivalent flow (mL/hr) & 2.4 & 28.7 \\
\hline Equivalent flow (mL/min) & 0.5 & 4.8 \\
\hline Backwash (mL/min) & 2.4 & 9.6 \\
\hline Counter current regeneration (mL/min) & 87.2 & 174.4 \\
\hline Regeneration 4-8 BV (mL) & 36.5 & 18.2 \\
\hline Regeneration time (min) & 87.2 & 174.4 \\
\hline Rinse Volume (mL) & 2.4 & 9.6 \\
\hline Rinse time (hr) & & \\
\hline
\end{tabular}




\section{Appendix D}

\section{RESIN CHARACTERISTICS}

DOWEXTM 21K XLT

\begin{tabular}{|c|c|c|c|}
\hline Product Name & Type & Matrix & Functional Group \\
\hline DOWEX 21K XLT & Type I Strong Base Anion & Styrene-DVB, Gel & Quaternary Amine \\
\hline
\end{tabular}

\begin{tabular}{|l|c|c|}
\hline \multicolumn{1}{|c|}{ Specifications } & Unit & $\mathrm{Cl}^{-}$Form \\
\hline Total Exchange Capacity, min. & eq/L & 1.3 \\
\hline Water Retention Capacity & $\%$ & $50-60$ \\
\hline Uniformity Coefficient & & 1.1 max. \\
\hline Particle Size Distribution & $\mu \mathrm{m}$ & $525-625$ \\
\hline Volume Median Diameter & $\%$ & 90 \\
\hline Whole Uncracked Beads, min. & $\%$ & $18-20$ \\
\hline Total Swelling $\left(\mathrm{Cl}^{-} \rightarrow \mathrm{OH}^{-}\right)$, approx. & $\mathrm{g} / \mathrm{mL}$ & 1.08 \\
\hline Particle Density & $\mathrm{g} / \mathrm{L}$ & 670 \\
\hline Shipping Weight** & $\mathrm{lbs} / \mathrm{ft} 3$ & 42 \\
\hline Shipping Weight** & & \\
\hline
\end{tabular}

** As per the backwashed and settled density of the resin, determined by ASTM D-2187.

${ }^{{ }^{\mathrm{TM}} \mathrm{M}^{*}}$ Trademark of The Dow Chemical Company ("Dow") or an affiliated company of Dow 


\section{DOWEX ${ }^{\mathrm{TM}}$ MARATHONTM MSA}

\begin{tabular}{|c|c|c|c|}
\hline \multicolumn{1}{|c|}{ Product Name } & \multicolumn{1}{|c|}{ Type } & Matrix & Functional Group \\
\hline $\begin{array}{l}\text { DOWEX MARATHON } \\
\text { MSA }\end{array}$ & Type I Strong Base Anion & $\begin{array}{l}\text { Styrene-DVB, } \\
\text { Macroporous }\end{array}$ & Quaternary Amine \\
\hline
\end{tabular}

\begin{tabular}{|l|c|c|}
\hline \multicolumn{1}{|c|}{ Specifications } & Unit & $\mathrm{Cl}^{-}$Form \\
\hline Total Exchange Capacity, min. & $\mathrm{eq} / \mathrm{L}$ & 1.1 \\
\hline Total Exchange Capacity, min. & $\mathrm{kg} / \mathrm{ft}^{3}$ as \\
$\mathrm{CaCO}_{3}$ & 24.0 \\
\hline Water Retention Capacity & $\%$ & $56-66$ \\
\hline Uniformity Coefficient & & $1.1 \mathrm{max}$. \\
\hline Whole Beads & $\%$ & $95-100$ \\
\hline Mean Particle Size & $\mu \mathrm{m}$ & $640 \pm 50$ \\
\hline Total Swelling (Cl- $\rightarrow$ OH-), approx. & $\%$ & 15 \\
\hline Particle Density & $\mathrm{g} / \mathrm{mL}$ & 1.06 \\
\hline Shipping Weight** & $\mathrm{g} / \mathrm{L}$ & 670 \\
\hline Shipping Weight** & $1 \mathrm{bs} / \mathrm{ft}^{3}$ & 42 \\
\hline
\end{tabular}

\footnotetext{
** As per the backwashed and settled density of the resin, determined by ASTM D-2187.

${ }^{\circledR} \mathrm{TM}^{*}$ Trademark of The Dow Chemical Company ("Dow") or an affiliated company of Dow
} 
$\operatorname{DOWEX}^{\mathrm{TM}} \mathrm{G}-26(\mathrm{H})$

\begin{tabular}{|c|c|c|c|}
\hline Product Name & Type & Matrix & Functional Group \\
\hline DOWEX G-26 $(\mathrm{H})$ & Strong Acid Cation & Styrene-DVB, Gel & Sulfonic Acid \\
\hline
\end{tabular}

\begin{tabular}{|c|c|c|}
\hline Specifications & Unit & $\mathrm{H}^{+}$Form \\
\hline Total Exchange Capacity, min. & eq $/ \mathrm{L}$ & 2.0 \\
\hline Water Retention Capacity & $\%$ & $45-52$ \\
\hline Uniformity Coefficient & & $1.1 \max$. \\
\hline $\begin{array}{l}\text { Particle Size Distribution } \\
\text { (Mean Particle Size) }\end{array}$ & $\mu \mathrm{m}$ & $650 \pm 50$ \\
\hline Whole Uncracked Beads, min. & $\%$ & 95 \\
\hline Crush Strength (Average, min.) & $\mathrm{g} / \mathrm{bead}$ & 500 \\
\hline Total Swelling $(\mathrm{Na}+\rightarrow \mathrm{H}+)$ & $\%$ & 7 \\
\hline Particle Density & $\mathrm{g} / \mathrm{mL}$ & 1.22 \\
\hline Shipping Weight** & $\mathrm{g} / \mathrm{L}$ & 800 \\
\hline Shipping Weight** & $\mathrm{lbs} / \mathrm{ft}^{3}$ & 49 \\
\hline Trace metals, ppm dry resin, $\max$ & 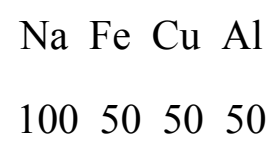 & $\begin{array}{c}\text { Heavy Metals (as } \mathrm{Pb} \text { ) } \\
20\end{array}$ \\
\hline Ionic conversion, min. & & $\mathrm{H}^{+} 99.7$ \\
\hline
\end{tabular}

${ }^{* \star}$ As per the backwashed and settled density of the resin, determined by ASTM D-2187.

${ }^{\circledR} \mathrm{TM}^{*}$ Trademark of The Dow Chemical Company ("Dow") or an affiliated company of Dow 
(BAYER) SYBRON IONAC C249

\begin{tabular}{|l|l|l|l|}
\hline \multicolumn{1}{|c|}{ Product Name } & \multicolumn{1}{|c|}{ Type } & \multicolumn{1}{c|}{ Matrix } & \multicolumn{1}{c|}{ Functional Group } \\
\hline $\begin{array}{l}\text { SYBRON IONAC } \\
\text { C249 }\end{array}$ & Strong Acid Cation & Styrene-DVB & Sulfonic Acid \\
\hline
\end{tabular}

\begin{tabular}{|l|c|c|}
\hline \multicolumn{1}{|c|}{ Specifications } & Unit & $\mathrm{Na}^{+}$Form \\
\hline Total Exchange Capacity, min. & eq/L & 1.9 \\
\hline Water Retention Capacity & $\%$ & $45-48$ \\
\hline Physical form & mesh & $16-40$ \\
\hline $\begin{array}{l}\text { Particle Size Distribution } \\
\text { (Mean Particle Size) }\end{array}$ & & \\
\hline pH range stability & $\%$ & $0-14$ \\
\hline Total Swelling (Na+ $\rightarrow \mathrm{H}+$ ) & $\mathrm{lbs} / \mathrm{ft}^{3}$ & 5 \\
\hline Shipping Weight** & $\mathrm{mg} / \mathrm{L}$ & 52 \\
\hline Maximum Free Chlorine & & 1 \\
\hline
\end{tabular}




\section{Vita}

Carlos Acevedo, son of Enrique Acevedo and Refugio Rodriguez, was born in 1966, in the City of León, Guanajuato, México. He got his Bachelor in Science in Chemical Engineering, in 1989 (Thesis: Improvements to the Wastewater Treatment Plant for "Química Central de México" (QCM)). From 1989 to 1997, he worked at QCM as coordinator of environmental projects for water, sewer and air pollution. Another position he occupied in the company was Industrial Safety Manager; his role in this position was to coordinate safety and environment projects. While working at this company, he also designed and built wastewater treatment plants, improved the industrial wastewater treatment plant for chromium recovery, designed a hazardous waste landfill, and managed projects for polluted areas remediation and chromium recovery processes.

He began working as a consultant and contractor for environmental projects in 1997, on his own company, Ingeniería y Proyectos Ecológicos, Sociedad Anónima (IPESA). Working in IPESA, he managed environmental projects for the tanning industry in Leon, Guanajuato. Designed and built wastewater treatment plants for domestic and industrial wastes; designed hazardous waste landfills, and advised many companies on environmental improvements and the compliance with environmental rules and regulations.

He worked as a mathematics and physics teacher in the "Universidad Anahuac" in Leon, Guanajuato from 1997 to 1999 and as teaching assistant at UTEP from 2001 to 2002.

In 2001 he moved to El Paso, TX and worked for the Lower Valley Water District, as New Installations Coordinator for one year. In 2001 he started his graduate program in Chemistry at the University of Texas at El Paso. In 2002 he was recruited by the Border Environment Cooperation Commission (BECC). At BECC he manages environmental projects along the USA-Mexico Border, having certified ten projects for water distribution, wastewater collection and treatment, and solid waste disposal. Currently he works at BECC as Project Engineer.

Permanent address: 3868 Lynwood St., El Paso, Texas, 79936

This thesis was typed by Carlos R. Acevedo. 